\title{
Neoliberal Politikaların Küresel Düzeyde Sağlık Üzerindeki Etkileri
}

\author{
The Global Impacts of Neoliberal Policies on Health
}

\author{
Yrd. Doç. Dr. Temmuz Gönç
}

\section{Öz}

Neoliberal politikalar ve sağlık arasındaki ilişki tartışılırken sağllk sıklıkla sağlık politikalarına indirgenmekte, neoliberal politikalarin etkisi de küresel düzeyde sağllk sistemlerinde yaşanan dönüşüm çerçevesinde değerlendirilmektedir. Halbuki sağlık, biyolojik faktörler ve sağhlk sistemlerinin yapısının yanı sıra yaşama, çalışma, barınma ve beslenme koşulları gibi çok sayıda ekonomik, sosyal ve politik faktör tarafindan da șekillendirilmektedir. Bu çalışma, dünya genelinde neoliberal politikaların sağlıkla ilgili sonuçları üzerine yapılış araştırmaların bir derlemesine dayanmaktadır. Çalışmanın amacı mevcut literatürdeki bulguları ilişkilendirerek toplum sağ̆lğının sadece sağlık sistemlerindeki dönüşümle değil, çalışma ve yaşama koşullarındaki dönüşüm ve eşitsizlikle ilişkili olduğunu vurgulamaktır. Diğer bir deyişle çalışma, neoliberal politikalarm sağlıkla ilişkili sonuçların farklı boyutlar açısından ele alarak neoliberalizmin sağlı üzerindeki etkilerini sağllk sistemlerinin dönüşümüne indirgemeksizin bütünlüklü, ilişsisel ve eleştirel bir bakış açısı içinde değerlendirmeyi amaçlamaktadır. Çalışma Türkiye’ye odaklanmamakta, neoliberal politikalarn küresel düzeyde toplum sağlğ̆ın hangi boyutlar üzerinden etkilediğini ortaya koymaya çalışmaktadır. Çalışmanin sonucuna göre mevcut literatürdeki ampirik bulgular, neoliberalizmin sağlı üzerindeki etkisinin sadece sağlık sistemlerinin dönüşümüyle sinırlı olmadığın göstermektedir. İşsizliğin artması, çalışma koşullarının kötüleşmesi, çevre, tarım ve gıda güvenliği, kentleşme ve beslenme konularında mevzuatın esnekleştirilmesi, sağlığa zarar verecek şekilde işleyen kapitalist işletmeler üzerinde devlet denetiminin zayıflamast ve toplumsal eșitsizliklerin derinleșmesi, neoliberal politikaların toplum sağı̆ğın olumsuz yönde etkileyen diğer boyutları arasinda yer almaktadir.

Anahtar Kelimeler: Sağllk Sosyolojisi, Sosyoloji, Neoliberalizm

\begin{abstract}
In the discussions on the relationship between neoliberal policies and health, health is frequently reduced to health policies and the effect of neoliberal policies are generally assessed only in the frame of global transformation of health systems. However, health is being shaped not only by biological factors and health systems, but also by economic, social and political factors like living, working, housing conditions and nutrition. This study depends on a compilation of the literature on the health related consequences of neoliberal policies on global scale. The aim of the study is to link the findings of the researches in the present literature and to emphasize that public health is related not only to the transformation of health systems and but also to the transformation of and especially the inequality in working and living conditions. In other words, the study aims to discuss the different dimensions of the health related consequences of neoliberal policies and to make a holistic, relational and critical evaluation of the impacts of neoliberalism on health. The study does not focus on Turkey, it tries to reveal the dimensions of the global impact of neoliberal policies on health. The empiric evidence of the present literature shows that the impact of neoliberalism on health is not limited to the transformation of health systems. The rise in unemployment; worsening of working conditions; increased flexibility of legislations regarding the security of environment, agriculture and food, urbanization and nutrition; weakening of state supervision on capitalist enterprises which harm public health and the deepening of social inequalities are the other dimensions of the impact of neoliberal policies on public health.
\end{abstract}

Keywords: Sociology of Health, Sociology, Neoliberalism

Yrd. Doç. Dr. Temmuz Gönç, Anadolu Üniversitesi Edebiyat Fakültesi, tgonc@anadolu.edu.tr 


\section{Giriş}

Sağlık hem bireysel hem de toplumsal yaşamın temel zeminidir, bu nedenle sağlıklı bir yaşam sürmek neredeyse bütün ülkelerin anayasalarında güvence altına alınmış ve İnsan Hakları Evrensel Beyannamesi'nde bir insan hakkı olarak kabul edilmiştir. Sağlık düzeyini belirleyen çok sayıda faktör söz konusudur ve bunların önemli bir kısmı yaşama, çalışma, barınma ve beslenme koşulları gibi toplumsal tabakalaşmayı yansıtan ve devletin sağlık politikaları kadar sağlık alanı dışındaki politikaları ile de ilgili olan faktörlerdir. $\mathrm{Bu}$ nedenle istihdam, ücretler, çalışma koşulları, çevre kirliliği, tarım ve gıda güvenliği gibi konularda devletin benimsediği ve uyguladığı politikalar toplum sağlığ 1 üzerinde sistematik bir etkiye sahip olmaktadır. $\mathrm{Bu}$ çalışma neoliberal politikaların sağlığı belirleyen ekonomik ve sosyal koşullar üzerindeki etkilerine odaklanmakta ve bu etkilerin toplum sağlığına nasıl yansıdığını eleştirel bir bakış açısıyla değerlendirmeyi amaçlamaktadır. Bu konu elbette bir makalenin kapsamını aşacak genişlikte ve derinliktedir, ancak bu çalışmanın özgün amacı, ekonomi politikaları ve sağlık arasındaki ilişki değerlendirilirken yalnızca sağlık hizmeti politikalarına odaklanmamak gerektiğini vurgulamak ve neoliberalizmin sağlık üzerindeki etkilerinin farklı boyutlarını bütünlüklü ve ilişkisel bir bakış açısı içinde değerlendirmektir. Çalışma spesifik olarak Türkiyedeki uygulamalara odaklanmamakta, genel olarak neoliberal paradigma içinde devletin toplumsal yaşamı düzenleyici rolünün zayıflamasının toplum sağlığını hangi boyutlar üzerinden etkilediğini ortaya koymaya çalışmaktadır. Bu amaçla öncelikle devlet ve toplum sağlığı arasındaki ilişki üzerinde durulacak, sosyal refah devleti politikalarının sağlık açısından sonuçlarına değinilecek, neoliberalizmin çalışma ve yaşama koşulları üzerinden sağlığı nasıl etkilediğine dair göstergeler incelenecek, son olarak neoliberal ekonomi politikaları ile küresel ölçekte görülen sağlık reformları arasındaki ilişki değerlendirilecektir.

Sağllk, biyolojik özellikler ya da alkol ve tütün kullanımı veya hareketsizlik gibi bireysel yaşam tarzı faktörleri tarafından etkilense de daha genel düzeyde, sağlığın sosyal belirleyicileri adı verilen bir dizi ekonomik, toplumsal ve politik faktör tarafından şekillendirilmektedir. Bu faktörlerden başlıcaları gelir ve eğitim düzeyi, barınma, beslenme ve çalışma koşulları, çevre kirliliği, barış ve insan hakları güvencesi, devlet tarafından iyi bir şekilde yönetilme ve etkili sağllk hizmetlerine erişimdir (Dahlgren ve Whitehead, 1992, s.5). Bu faktörlerin etkisi nedeniyle bireylerin sağlık düzeyleri toplumsal sınıflarına (Navarro, 2002; Scambler ve Higgs, 1999), gelirlerine (Leigh vd.2009), istihdam statülerine ve çalışma koşullarına (Cylus vd., 2015; Sanwald ve Theurl, 2014; Laaksonen vd.2006) ve sosyal statülerine (Marmot, 2004; Bernstein vd., 2015) göre farklılık göstermekte ve bu faktörler açısından dezavantajlı olan grupların sağlıkları da kötüleşmektedir. Yoksulların, azınlıkların, kadınların ya da başka türden sürekli olarak sosyal dezavantaja maruz kalan grupların sağlıklarının toplum geneline oranla sistematik olarak daha kötü olması 'sağlık eşitsizliği' kavramıyla açıklanmaktadır (Braveman, 2006, s.167). Eşitsizlik ve sağlık arasındaki bu ilişki sağlı̆̆ı sadece bireysel olarak değil, toplum düzeyinde zedelemektedir. Toplum sağllğ 1 , toplum tarafından bütün nüfusun sağlığının korunması ve iyileştirilmesi yönünde kolektif bir eylemdir ve temel olarak sağlığın sosyal belirleyicileri tarafından şekillenir. Bu nedenle toplum sağlığı eğitim düzeyinin yükselmesine, işsizliğin kontrol altına alınmasına, çalışma koşullarının iyileştirilmesine, kadınların özerkliğine, yaşlıların ve yoksulların toplumsal dışlanmışl1ğının azaltılmasına, yeterli beslenmeye, gıda üzerinde sıkı denetim uygulanmasına ve ulaşılabilir ve yeterli koruyucu sağlık hizmetlerine bağlıdır (Marmot ve Wilkinson, 1999; Beaglehole ve Bonita, 1997).

Günümüzde tıp ilerlemekte fakat neoliberal politikaların sağlığın sosyal belirleyicileri üzerindeki bozucu etkisi (Beaglehole ve Bonita, 1997, s.xiii) nedeniyle toplum sağlı̆̆ 1 zarar görmektedir. Neoliberal politikaların sağlıkla ilişkisi değerlendirilirken sıklıkla Uluslararası Para Fonu (IMF) ve Dünya Bankası gibi küresel kurumların yönlendirmesi nedeniyle sağllk sistemlerinde yaşanan dönüşümlere odaklanılmakta ve sağlık politikaları konusu sıklıkla "sağlık hizmeti politikalarına indirgenmekte, hatta tekeline alınmaktadır" (Mooney, 2014, s.59). Halbuki sağlık yalnızca sağlık hizmetlerinin tasarlanmasına ve uygulanmasına bağlı değildir, bu nedenle devletin sağlık konusundaki rolü veya ekonomi politikalarının sağlık üzerindeki etkileri değerlendirilirken çok boyutlu ve bütünlüklü bir çerçeve izlenmeli, toplum yaşamında sağlığı etkileyen alanlar birlikte değerlendirilmelidir. 


\section{Yöntem}

Bir derleme olan bu çalışmanın amacı, neoliberal politikaların toplum sağlığı üzerindeki etkilerinin farklı boyutlarını ilişkilendirmek ve neoliberalizmin sağlık üzerindeki etkilerinin sağlık sistemlerinin dönüşümü ile sınırlı olmadığını vurgulamaktır. Bu amaçla neoliberal paradigmada devletin düzenleyici ve kontrol edici rolünün zayıflamasının istihdam ve çalışma yaşamı, çevre, tarım ve gıda güvenliği, kentleşme, beslenme ve sağlık sistemleri üzerindeki etkilerini ortaya koyan çalışmalar taranarak derlenmiştir. Çalışma, mevcut literatürdeki bulgular üzerinden neoliberalizmin sağlık üzerindeki etkilerinin farklı boyutlarını bütünlüklü bir şekilde değerlendirmeye ve ekonomi politikaları ve sağlık arasındaki ilişki ele alınırken yalnızca sağlık hizmeti politikalarına odaklanmanın sınırlılığını vurgulamaya çalışmaktadır. Bu çerçevede ilk olarak devlet ve toplum sağllğı arasındaki ilişki üzerinde durulacak, ikinci olarak neoliberal politikalar ile birlikte çalışma ve yaşama koşullarında yaşanan değişimlerin sağlık üzerindeki etkileri hakkında mevcut literatürdeki bulgular incelenecek, daha sonra neoliberal politikaların sağlık sistemlerinde yarattığı dönüşüm ele alınacak, son olarak toplumsal eşitsizliklerin derinleşmesinin sağlık üzerinde yarattığı sonuçlar değerlendirilecek ve sonuç bölümünde ilişkisel bir değerlendirme yapılacaktır.

\section{Toplum Sağlığı ile Devletin Rolü Arasındaki illişki}

Toplum sağllğının bir devlet meselesi haline gelmesi ancak modern toplumun gelişiminden sonra söz konusu olmuştur. Modern toplum, kitlesel göçlerle birlikte nüfusun büyük ölçüde kentlerde yaşamaya başladığı, endüstriyel işçi sınıfının doğduğu ve siyasal olarak ulus devlet şeklinde bir örgütlenme yapısının olduğu bir toplumdur. Endüstri devrimi sonrasında henüz devlet tarafindan düzenlenmeyen, yasal sınırlılıkların ve yasaların henüz oluşmadığ çalışma yaşamında ağır koşullar söz konusudur ve büyümekte olan kapitalist işletmelerin bu koşullara uyarak çalışabilecek sağlıklı bir işgücü kitlesine ihtiyacı vardır. Diğer taraftan sömürgecilik savaşlarının ve Birinci Dünya Savaşı̉nın arifesinde modern devletler, ulusal orduları oluşturacak sağlıklı askerlere de ihtiyaç duyarlar. Ancak yasal düzenlemelerin eksikliği nedeniyle uzun çalışma saatleri boyunca düşük ücretlerle çalışan, yetersiz beslenen, endüstrinin dayandığı kömür enerjisi nedeniyle hava ve çevre kirliliği içinde ve sağlıksız barınma koşullarında yaşayan işçiler sağliksızdır (Engels, 1845). Hatta savaşa giren ülkelerde asker-işçiler silahları taşıyamayacak kadar zayıftır (Dussault ve Sheilham, 1982). Hasta ve aç işçiler, endüstriyel ve askeri alanlarda devletin ihtiyaç duyduğu kitlesel beden ihtiyacını karşılayamamış ve ekonomik ve askeri büyümenin önünde bir engel oluşturmuşlardır. Bu dönemde kitlesel olarak hasta, yoksul ve aç olan işçi sınıfı üzerinde yapılan çalışmalar yoksulluk, eşitsizlik ve sağlık arasındaki ilişkinin ilk defa ortaya konmasını sağlamıştır. Engels'in (1845) İngiltere'de işçi sınıfının yaşam koşullarını ortaya koyduğu eseri ve Henry Mayhew'in (1861) Londra'daki yoksullar üzerine yaptığ 1 çalışma kapitalistlerin kontrolsüz bir şekilde kâr amacı peşinde koşmalarının çalışma ve yaşama koşullarını kötüleştirerek hastalıklara neden olduğunu ve böyle bir yapı içinde bireylerin kendi sağlıklarını koruyacak güce sahip olmadıklarını göstermiştir. Bu çalışmalar hastalığın toplumda tesadüfi bir yolla yayılmadığını, yoksulluğun yoğunlaştığı yerlerde, gecekondu mahallelerinde ve endüstriyel işlerde daha fazla görüldügünü ortaya koymuştur (Engels, 1845; Mayhew, 1861). Öte yandan, sağlıklı işgücü ve ordu ihtiyacı devletleri sağlık konusunun bireylerin kendilerine bırakılamayacak kadar önemli olduğuna ikna etmiş, hastalıkları önlemek amacıyla beslenme, barınma ve çalışma koşullarını iyileştirmek üzere devlet müdahalesinin gerekli olduğu kabul edilmiştir. Bu koşullar 1930 bunalımı ile birleşerek sosyal refah devletinin başlangıcını oluşturmuş ve İkinci Dünya Savaşı sonrasından 1970'lerin sonuna dek devlet müdahaleleri sayesinde işçilerin ücretleri artmış, yaşam koşulları ve sağlıkları iyileşmiş̧tir (White, 2002, s.58). $\mathrm{Bu}$ süre boyunca sosyal refah devleti çalışma yaşamını düzenleyerek, eğitim, sağlık, barınma alanlarında sorumluluk üstlenerek, sosyal sigortacılık anlayışını geliştirerek, sosyal yardım ve kazanımları erişilebilir kılarak toplumun hastalık, yaşlılık, işsizlik ve yoksulluk gibi sosyal riskler karşısında korunmasını sağlamıştır. Tam istihdamı hedeflediği için işsizliği belirli bir seviyede tutmuş, işletmeler üzerinde devlet denetimi ve düzenlemeleri güçlü olduğu için çevre kirliliğini ve gıda güvenliği sorunlarını kontrol altına almıştır. Toplum sağlığının iyileşmesini sağlayan bu koşullara ek olarak ulusal sağlık sistemleri aracılığıyla sağlık hizmetlerini finanse etme ve sunma işlevini üstlenmiştir. 
Ancak 1970'lerin sonundan itibaren pek çok ülkede neoliberal ekonomi politikalarını benimseyen Yeni Sağ partilerin iktidara gelişi ile birlikte sosyal refah devleti zayıflamaya başlamıştır. Neoliberal ideoloji bireyciliği, özelleştirmeyi, düzensizleşmeyi, merkezsizleşmeyi savunan bir ideolojidir ve iktidara gelişiyle birlikte serbest ticaret için gerekli ortamın yaratılması doğrultusunda devlet müdahalesinin ortadan kaldırılması ya da en düşük düzeye indirilmesi süreci başlamıştır. “Toplum diye bir şey yoktur, sadece birey vardır" sözüyle hatırlanan Margaret Thatcher'in iktidarda olduğu 1988 yılında bireylerin sağlıklı yaşam tarzlarına ulaşabilecekleri toplumsal çevreyi korumaya çalışması üzerine bir bakanın "dadı devlet" yanlısı olmakla itham edilerek görevine son verilmesi (Secretary of State for Health, 1988, s.28'den aktaran White, 2002, s.59) neoliberal politikalarm ne kadar keskin uygulandığının kanıtları arasındadır.

Küreselleşme ve neoliberalleşme sürecinde ticari ve siyasal anlamda ulus devletlerin zayıflaması devletlerin sadece ekonomi politikalarını değil, çalışma yaşamı, kentleşme, çevre ve sağlıkla ilgili politikalarını da etkilemiştir. Neoliberalizm sonrasında Dünya Bankası'nın ve IMF’nin borç ve kredi düzenlemeleri ve yapısal uyum programları ile birlikte hem gelişmiş hem de azgelişmiş ülkelerde devletler elektrik, su, ulaşım ve liman hizmetlerini özelleştirmeye, kamu eğitimi ve sağlık hizmetlerini bünyelerinden ayırmaya başlamışlardır (Labonte, 1998). Bu politikalar işsizliğin ve yoksulluğun artmasında etkili olmuş, özel işletmeler üzerindeki devlet denetiminin azalmasıyla birlikte 1980 sonrasında dünya genelinde çalışma koşulları kötüleşmeye, tarım ve gıda güvenliği zedelenmeye başlamıştır. Aynı dönemde bilim ticarileşmeye ve sağlık metalaşmaya başladığı için bu politikaların toplum sağlığı üzerindeki olumsuz etkilerini ortaya koymaya çalışan bilimsel çalışmalar büyüyen endüstriler tarafından büyük ölçüde engellenmiştir. Bunlara ek olarak toplumun dikkati hastalıkların ardındaki toplumsal, ekonomik ve çevresel faktörlerden uzaklaştırılmış, hastalıklara bireysel yaşam tarzı faktörlerinin neden olduğu vurgulanarak sağlığın bozulmasının sorumluluğunu bireye yüklenmiş (Crawford, 1984), bu çerçevede sağlık ve kamu hizmeti arasındaki ilişki çözülmüştür.

1 Dadı devlet (nany state) terimi, yurttaşları fazla koruyan ve yurttaşlar tarafından fazla güvenildiği düşünülen, refah üzerinde aşırı kontrole sahip ve otoriter olduğu düşünülen devleti ifade etmektedir.

\section{Neoliberal Politikaların Sağlıkla İlgili Sonuçları}

İşsizlik, Yoksulluk ve Çalışma Yaşamında Esneklik

Neoliberal politikalarla birlikte tam istihdam devletler için bir hedef olmaktan çıkmış, işsizlik artmış, reel ücretler düşmüş, kayıt dışı çalışmanın daha yaygın olduğu hizmet sektörü genişlemiş, istihdam formel sektörden enformel sektöre kaymış, güvencesiz ve örgütsüz çalışma artmıştır. İşsizlikle ölüm oranları arasındaki iliş̧i çarpıcıdır. A.B.D.de 1980-2006 yılları arasındaki ölüm kayıtlarını inceleyen bir çalışma (Sullivan ve von Wachter, 2009), istihdam edilenlere oranla işsiz kalanların on ila on beş yıl içinde ölme risklerinin en az yarı yarıya daha yüksek olduğunu göstermektedir. Özellikle uzun dönem işsizliğin söz konusu olduğu durumlarda depresyona bağlı intihar oranları da yükselmektedir (Classen ve Dunn, 2012). İşsizlik yalnızca ölüm oranlarını değil, hastalanma oranlarını da etkilemektedir. İşsizler arasında kalp ve damar hastalıkları gibi fiziksel hastalıkların ve depresyon, anksiyete gibi zihinsel sorunların daha yaygın olarak görüldüğü 1930'lardaki çalışmalardan (Marsh vd., 1938) bu yana bilinmektedir. Son zamanlarda yapılan çalışmalar da benzer bulgular sunmaktadır, işsizlik fiziksel (Burgard vd., 2007; Hammarstrom, 2005) ve zihinsel (Catalano vd.2015) hastalık oranlarında artışa neden olmaktadır. İstihdam edilmiş olanlara oranla işsizlerin sağlığ $1 \% 54$ daha kötüdür ve strese bağlı kalp krizi geçirme, kalp hastalığ 1 ya da romatizma hastalıklarına sahip olma oranları \%83 daha yüksektir (U.S. Bureau of Labor Statisitics, 2013). İşsizliğin en önemli sonuçlarından biri yoksulluktur ve yoksulluk da hastalık ve ölüm oranlarını yükseltmektedir. Yaş ve cinsiyet değişkenleri kontrol altında tutulduğunda en yoksul olanların iskemik kalp hastalığına, akciğer kanserine ve bronşite bağlı ölüm oranları en zengin olanların iki katından daha fazladır (McLoone ve Body, 1994). Yoksullukla ilişkili bir hastalık olduğu bilinen tüberküloz vakalarının dünya genelinde \%85'i dünyanın en yoksul kıtalarında, Afrika ve Asya'da görülmekte, Hindistan ve Çin'deki vakalar toplam vakaların üçte birinden fazlasını (\%35) oluşturmaktadır (Tahaoğlu vd., 2012, s.7). İşsizlik sağlığ1 sadece yetersiz beslenmeye ya da kötü barınmaya yol açan yoksulluğa bağlı olarak değil, göreli mahrumiyet, toplumsal izolasyon ve kendine güven kaybı yaratarak da (Bartley, 1994, s. 333) etkilemektedir. Göreli mahrumiyet içinde yaşayanların hissettiği umutsuzluk, endişe, güvensizlik ve kızgınlık duygu- 
ları bir yandan bağışıklık sistemlerini zayıflatmakta, diğer yandan yüksek alkol tüketimi, çok yağlı ve çok şekerli besinlere yönelme gibi olumsuz sağlık davranışlarına neden olmaktadır (Annandale 1998, s.94). $\mathrm{Bu}$ bulgular sağlığı iyileștirmenin en önemli ve kesin yollarından birinin işsizliği azaltmak ve ücretleri artırmak olduğunu göstermektedir. Ancak 2013 yılında işsizlik oranları Yunanistan'da \%27.6, İspanya'da $\% 26.7$, Türkiye'de \%9.9, A.B.D.'de ve İngiltere'de \%7.5'tir ve Uluslararası Çalışma Örgütünün tahminlerine göre bu oranlar önümüzdeki yıllarda pek çok ülkede artmaya (ILO, 2014) ve toplum sağlığını bozmaya devam edecektir. Dolaylı olarak işsizliğe neden olan çok sayıda faktör söz konusu olsa da asıl nedenin yeni teknolojiler ya da esnek üretim değil, maliyet azaltmak için emeğe yönelen neoliberal politikalar olduğu (Navarro, 1998) vurgulanmaktadır.

Öte yandan istihdam edilecek kadar şanslı olanların çalışma koşulları ise işyerinin, istihdam biçimlerinin, çalışma saatlerinin ve ücretlerin esnekleşmesi nedeniyle kötüleşmektedir. Neoliberal politikalar çerçevesinde bir yandan küresel rekabetin artması, diğer yandan iş yasalarının esnekleştirilmesi işçilerin güvencesiz ve örgütsüz șekilde, uzayan iș saatlerinde, artan iș temposunda, zehirli kimyasallara maruz kalarak ve işçi sağlı̆̆ 1 ve iş güvenliği açısından kötü koşullarda çalışmalarına yol açmaktadır. Güvencesizliğin yaygınlaştı̆̆ 1 ve işsiz kalma korkusunun bile en önemli stres kaynaklarından biri haline geldiği günümüzde işten çıkarılma korkusunun tansiyon sorunlarına, obeziteye ve psikolojik sorunlara neden olduğu ortaya konmuştur (Reichert ve Tauchmann, 2011; Ferrie vd.,2002). Üstelik iş güvencesinden yoksun kalmanın sağlık üzerindeki olumsuz etkileri o kadar ciddidir ki işi kaybetme tehdidini oluşturan durum ortadan kalktığında bile sağlık eski düzeyine yükselmemektedir (Burgard vd., 2009). Güvencesiz çalışmanın en somut hali sözleşmeli çalışmadır ve taşeron çalışanların büyük kısmı bu şekilde çalışmaktadır. Taşeron çalışma, genellikle sözleşmeli, yevmiye üzerinden çalışan, hastalık halinde işe gelemediklerinde ücretleri kesilen, prim, ikramiye, kıdem tazminatı, yiyecek içecek yardımı, yıllık izin hakkı olmadan çalışan, iş güvenliği ile ilgili kalitesiz malzemelerle çalışan işçileri kapsamaktadır ve 2011 yılında Türkiye'de 1 milyon 611 bin kişi taşerona bağlı olarak çalışmaktadır (DİSK, 2014).
Çalışma sırasında yapılan iş üzerindeki kontrol ve özerklik azaldıkça kalp hastalığına yakalanma oranı artmaktadır, üstelik bu ilişki, kalp hastalığına neden olabilecek diğer nedenler, tütün kullanımı, tansiyon, kolesterol seviyesi ve glikoz toleransı gibi risk faktörleri hesaba katıldıktan sonra bile varlığını sürdürmektedir (Wilkinson, 2000, s.6). Yapılan iş üzerinde kontrol düzeyi azaldıkça tehlikeli kimyasallara ve gürültüye maruziyet, rutin ve tekrara dayalı çalışma ve vardiyalı çalışma oranları artmakta ve sağlık statüsü kötüleşmektedir (Laaksonen vd., 2006). Vardiyalı çalışma ve fazla mesai uyku bozukluğu, bitkinlik, anksiyete, depresyon, ters kardiyovasküler etkiler, gastrointestinal bozukluklar, düşük ve erken doğum riski, kaza olasılığının artması gibi etkilere sahiptir (Harrington, 2001). Vardiya, işçilerin özerkliğe sahip olmadığı tek alan değildir. İşin ve işçilerin esnekleştirilmesi, bir yandan işçilerin vasıf düzeylerine göre bölünmelerine ve işle ilgili stresin artmasına, diğer yandan işçilerin çok vasıflı hale getirilerek iş yüklerinin artırılmasına neden olmaktadır. Ancak iş yükleri artsa ve iş tempoları yükselse de işçiler işsizlik korkusu ve yeni yönetim teknikleri nedeniyle stres altında çalışmaya devam etmektedirler. İşin yarattığı stres psikolojik bozukluklara, kalp damar hastalıklarına, kas ve iskelet sistemi hastalıklarına, kansere, ülsere, ve bağışıklık sistemi hastalıklarına yol açmaktadır ve yüksek düzeyde iş stresi altında çalıştığını belirten işçilerin sağlık harcamaları diğer işçilere oranla $\% 50$ daha fazladır (Goetzel vd., 1998). Bununla birlikte hem işsiz kalma korkusu artan iş yoğunluğuna ve iş stresine dayanmayı gerekli kıldığı, hem de özellikle gelişmekte olan ülkelerde hiç hastalık izni kullanmadan çalışıldığg takdirde alınan "işe gelme primi" nedeniyle, özellikle güvencesiz işçiler hastalık halinde de çalıșmaya devam etmektedirler. İșe devamsızlık oranının Norveç ve Finlandiya'da ortalama 8,5 günken Türkiyede 3 günün altında (Eurofound, 2012, s.56) olması işçilerin sağlıklı olduklarını değil, sağlıklı olduklarını iddia ettiklerini göstermektedir.

Neoliberal politikalar azgelişmiş ülkelerde olduğu kadar gelişmiş ülkelerde de çalışma biçimini değiştirmiştir. 1980 sonrasında özellikle gelişmiş ülkelerde haftada beş ya da altı gün ve gündüzleri sekiz saatle sınırlandırılmış geleneksel çalışma yerine geçici veya kısmi süreli çalışma, iş paylaşımı, evde çalışma ya da çağrı üzerine çalışma gibi atipik istihdam biçimleri 
yaygınlaşmıştır (Liptak, 2011). Atipik istihdamın sağlık üzerine etkileri hakkında 26 ülkede yapılmış toplam 50 araştırmanın bulgularını inceleyen bir çalışma (Sanwald ve Theurl, 2014) atipik şekillerde istihdam edilmenin çok sayıda hastalığın nedenleri arasında olduğu, fiziksel ve zihinsel sağlığ kötüleştirdiği sonucuna varmıştır.

Çalışma yaşamında kâr amacının insan sağlığının önüne geçmesinin bir diğer sonucu da meslek hastalıklarının ve iş kazalarının önlenememesidir. Uluslararası Çalışma Örgütü, her gün işe bağlı nedenlerle 6300 ölümün yaşandığını, bunların \%87'sinin meslek hastalıkları ya da işe bağlı hastalıklar nedeniyle gerçekleştiğini ve yılda 160 milyon işe bağlı hastalık vakası görüldügünü belirtmektedir (ILO, 2011). Her yıl, sadece çalışırken kimyasallara ve toza maruziyete bağlı akciğer hastalıklarından ve kanserlerden 13 bin ișçi ölmektedir (WHO, 2014a). Dünya Sağlık Örgütü’ne (DSÖ) (2014a) göre sadece 2013-14 yıllarında 1,2 milyon işçi işe bağlı nedenlerle kas ve iskelet sistemi hastalıklarına yakalanmıș, depresyon ya da kaygı bozukluğu yaşamıştır. Türkiye'de 2011 yılında 140 bin 594 iş kazası ve 395 meslek hastalığ görülmüştür (SGK, 2012). Bu verilerin iyimser olduğu ileri sürülebilir, çünkü hem veriler sadece kayıtlı işçileri kapsamaktadır hem de hastalıklara meslek hastalığı tanısı konması sürecinde çeşitli belirsizlikler ve bürokratik zorluklar söz konusudur. Türkiye'de mesleğe bağlı hastalıklara ilişkin resmi rakamların gerçekleri yansıtmaktan uzak olduğu, özellikle Çalışma Bakanlı̆̆ı’nın verilerinin TÜIK verilerinden bile oldukça düşük çıktığı (Kapusuz, 2008) belirtilmektedir. Güvencesiz ve kayıt dışı çalışma, düşük ücretler, uzun çalışma saatleri ve işyeri hekimlerinin mali olarak işletmenin işverenine bağlı olması, meslek hastalıklarının etkisini artırmaktadır (Süyür, 2009, s.10-11). Meslek hastalıklarının yanı sıra iş kazaları da dünya genelinde her yıl 350 bin işçinin önlenebilir nedenlerle ölümüne yol açmaktadır (WHO, 2009, s.25). İş kazalarının yüksekliğinin temel nedenlerinden birinin iş sağlığı ve güvenliği bakımından işbaşı eğitimi ve hizmet içi eğitim şartının, işverenlerce 'zaman ve maliyet kaybı' olarak görüldüğü için mevzuatta öngörüldüğü ölçüde yerine getirilmemesi (Aydın vd., 2013) olduğu vurgulanmaktadır. Dolayısıyla iş yasalarının esnekleştirilmesi, işverenlere uygulanan yaptırımları azalttığı için iş kazalarının da meslek hastalıklarının da önlenmesini zorlaştırmaktadır. Üstelik işçilerin iş sağlığ 1 ve güvenliği hizmetlerine erişim oranları da ülkelere göre farklılık göstermekte, gelişmekte olan ülkelerde işçilerin en fazla beşte biri bu hizmetlere ulaşabilmektedir (Rantanen, 2010, s.170). Kaldı ki işçi sağlığ ile ilgili verileri paylaşan işyeri hekimlerinin işveren tarafından 'sadakatsizlik'le suçlanarak işten çıkarılması (Cumhuriyet, 2014) işçi sağ lı̆̆ı hizmetlerine erişebilir olmanın tek başına yeterli olmadı̆̆ını göstermektedir.

Kısacası neoliberal yeniden yapılanma çalışma yaşamında özelleştirme, işsizlik, taşeron çalışma, atipik istihdam ve güvencesizlik gibi mekanizmalarla işçi sağlığını olumsuz etkilemektedir. 1980'lerin sonundan 2000'lerin sonuna dek işçi sağlığı ve iş güvenliği ile ilgili yapılmış çalışmaların \%85'inin işçi sağlı̆̆ının kötüleştiği bulgusuna ulaşmış olması (Quinlan ve Bohle, 2009) bu olgunun sistematikliğini göstermektedir. Türkiye'de son yıllarda giderek daha sık karşılaşılan iş kazaları ve tersanelerde, kot taşlama atölyelerinde ve maden ocaklarında yaşanan işçi ölümleri özelleștirmenin, taşeronlaștırmanın ve maliyetleri düşürme çabasının neden olduğu önlenebilir ölümlerdir (TMMOB, 2008). Bununla beraber sistematik bir desene sahip olan bu ölümler işletmeler ve işverenler tarafından işçilerin bireysel davranışları nedeniyle oluşan kazalar (Arslan ve Durukanoğlu, 2008, s.27) olarak görülmektedir.

\section{Çevre, Tarım ve Gıda Güvenliği}

Su kaynakları, tarımsal üretim ve gıda üretimi konularında devlet denetiminin ve kontrolünün azalması sağllğa doğrudan zarar vermektedir. DSÖ’ye göre su ve gıda kirliliği "toplum sağlığına küresel bir tehdit ve toplumsal azgelişmişliğin temel bir göstergesi" (WHO, 2014d) olarak kabul edilmektedir. Su ve gida kirliliğine bağlı olarak görülen ve dünya genelinde yirminci yüzyılın başında hijyen koşullarının iyileşmesiyle ortadan kalktığ düşünülen (White, 2002, s.59) kolera hastalığı günümüzde dünyanın pek çok ülkesinde yeniden salgınlar halinde görülmektedir (WHO, 2014b). Örneğin 1991-1994 yıllarında Amerika kıtasında yaşanan salgında bir milyonun üzerinde kolera vakası görülmüş ve bunların on bine yakını (9,642 vaka) ölümle sonuçlanmıştır (CDC, 1995). 2014 yilında ise Güney Sudan'da başlayan salgının etraftaki bölgelere sıçramasından endişe edilmektedir (WHO, 2014c). Kolerayı önlemenin en etkili yolu temiz su kaynaklarına ve hijyene erişimin sağlanmasıdır (WHO, 2014b) ancak dünya genelinde 748 milyon insanın temiz içme suyuna, yaklaşık 2,5 
milyar insanın ise temel kanalizasyona erişimi yoktur (WHO, 2014e). Dünya Bankası, özellikle gelişmekte olan ülkelerde verimli kullanılmadığını ileri sürerek su kaynaklarının özelleștirilmesini talep etmektedir (WB, 2004:16). Ancak su kaynaklarının özelleştirilmesinin hem su kirliliğine yol açacağı hem de artan fiyatlar nedeniyle yoksulların suya erişimini kısıtlayacağ (Spronk, 2010, s.159, 170) vurgulanmaktadır. Su kaynaklarına erişimi olanlar da tehlike altındadır, örneğin 2002 yılında Kanada'da deregülasyon nedeniyle su kaynaklarının yeterince kontrol edilmemesi içme suyunun kirlenmesine ve binlerce insanın zehirlenmesine ve hastalanmasina neden olmuştur (Prudham, 2004). Gıda hazırlama ile ilgili yasal düzenlemelerin esnekleştirilmesi de 1990’lar boyunca yiyecek zehirlenmelerinde artışa neden olmuştur (Thomson vd., 1998).

Çevre yasalarının kontrolsüz çalışan endüstriyel işletmeler lehine esnetilmesi çevre kirliliğini artırmakta ve büyük çapta ölüme ve hastalığa yol açmaktadır. Dünya genelindeki ölümlerin ve hastalıkların yaklaşık \%10’u çevre kirliliğinin yarattığı fiziksel, kimyasal ve biyolojik risklerden kaynaklanmakta, beş yaşın altındaki her dört çocuktan biri bu nedenle ölmektedir (WHO, 2009, s.23). Bu risklerin en önemlilerinden biri gıda güvenliğidir. Gıda güvenliği, herkesin, her zaman sağlıklı ve aktif bir yaşam sürmek için gerekli olan günlük beslenme ihtiyaçlarını ve gıda tercihlerini karşılayacak yeterli, güvenli ve besleyici gıdaya erişmesidir (FAO, 1996). Dünyada yeterince gida olmasına rağmen (WHES, 2014), 2014 yllında 805 milyon insan açlık içindedir ve her yıl beş yaş altındaki çocuk ölümlerinin yarısına yakınının (\%45) nedeni açlıktır (UNDP, 2014b). Açlık çeken insanların büyük bölümünü azgelişmiş ülkelerde ve kırsal alanlarda yaşayanlar, çocuklar, kadınlar ve yaşlılar oluşturmaktadır (FAO, 2014). Kırsal kesimde açlık daha yoğun görülse de açlığın en önemli nedeni eşitsizlik ve yoksulluk olduğu için kentsel alanlarda da gidaya erişim ekonomik nedenlerle sinırlanmaktadır. 1996 yılında genetiği değiştirilmiş organizmalar içeren ürünlerin ticarileşmesine izin verilirken bu ürünlerin daha çevreci ürünler olacağı ve açlıkla mücadelede etkili bir araç olacağı ileri sürülmüştür (Aslan ve Şengelen, 2010, s.11). Ancak açlık oranları, özellikle azgelişmiş ülkelerde hâlâ \%15'in altına düşmemiştir ve Birleşmiş Milletler Gıda ve Tarım Örgütü bunun kabul edilemez bir oran olduğunu vurgulamaktadır (FAO, 2014). Bu durumun nedeni açlı̆̆ın besin yetersizliğinden değil, kaynakların eşitsiz dağılımından kaynaklanmasıdır. Açlık; kapitalizm, sömürgecilik, emperyalizm, ırkçılık ve ataerkillik tarafından yaratılan yoksullukla bağlantılıdır ve temelleri adaletsizlikle örülmüș bölüşüm kurumlarından kaynaklanmaktadır (Albritton, 2011, s. 214). Yetersiz beslenen insanların \%98'i azgelişmiş ülkelerde yaşamaktadır ve bu nüfusun yarısına yakını sadece Çin ve Hindistan'da yaşayanlardan oluşmaktadır (FAO, 2010). Gıdanın bol olduğu alanlarda yaşamak da gıda güvenliğini garanti altına almamaktadır. Son yıllarda sağlıklı gıdaların kalitesiz, pahalı ve erişilemez olduğu düşük gelirli bölgelere "gida çölü" adı verilmekte ve bu bölgelerde obezitenin ve beslenmeye bağlı kronik hastalıkların artış gösterdiği belirtilmektedir (Shanon, 2014, s.248).

Açlıkla mücadele etme amacıyla meşruiyet kazanan GDO'lu ürünlerin içindeki tarım ilacı oranları, üretildikleri ilk yıllarda düşük olsa da hızla ve büyük oranda artmaktadır (Aslan ve Şengelen, 2010, s.1112). Bu ürünlerin dünya açlığını değilse de işletme maliyetlerini azaltmaları söz konusu olabilir, nitekim bir gıda işletmesi, kızartma sırasında daha az yağ emmesi, böylece pişme süresini, kullanılan yağı ve yakıtı azaltarak maliyetleri düşürmesi amacıyla patates bitkisine nişasta üreten bir gen yerleştirmeyi hedeflemektedir (Korkut ve Soysal, 2013, s.8-9). Ayrıca GDO’lu tarım ürünleri biyolojik çeşitliliği azaltarak açlığı artırma, toksik etkiler yaratma ve antibiyotik direncini artırma riski de taşımaktadır (Meseri, 2008). Beslenme yoluyla sağlı̆̆ doğrudan olumsuz etkileyen bu ürünler, her yıl yeni tohum satın almayı gerektirdiği için tohum alımında dışa bağımlılık yaratmakta ve tarım üreticilerini yoksullaştırmaktadır. Örneğin, Hindistan’a özgü basmati pirincinin genlerini işleyen ve yeni bir isimle patentini alan bir firma, artık basmati pirincinin ve gelecekte bu türden üretilecek bütün türlerin mülkiyetine sahip sayıldığı için Hindistan'dan bu pirincin ihracatında patent hakkı istemiştir (Korkut ve Soysal, 2013, s.20). TRIPS anlaşması genetik materyalleri, çekirdek plazmalarını ve mahsulleri özel mülkiyet olarak tanımladığı için bu ürünleri üreten toplumların çokuluslu şirketlere kullanım ücreti ödemek zorunda kaldığını vurgulayan Harvey (2012, s.80), biyokorsanlığın denetimsiz olduğunu ve yakında dünyanın genetik kaynaklar stokunun birkaç büyük ilaç firması tarafından yağmalanacağını belirtmektedir. Tarım ve gıda üretimi konusunda devletin denetim ve kontrol eksikliği önümüzdeki yıllarda daha fazla ölüme ve hastalığa neden 
olacak gibi görünmektedir. Nitekim tarım ilaçlarının kontrolsüz ve yanlış kullanımı özellikle cilt, akciğer ve mesane kanserinin en önemli nedenleri arasindadır (Oberoi vd., 2014). Kanser giderek daha fazla insanın yakalandığı bir hastalıktır ve DSÖ önümüzdeki 20 yıl içinde yeni kanser vakalarının \%70 oranında artacağını öngörmektedir (WHO, 2014f).

Çevre, tarım ve gida üzerinde denetim ve kontrolün artırılması pek çok hastalığın azalmasını sağlayabilir. Çevresel koşulların iyileştirilmesiyle trahom ve sistozomyas hastalıklarının tamamen ortadan kaldırılabileceği, sitmanın \%42, şagas hastalığının \%56 oranında azaltılabileceği (Üstün ve Corvalan, 2006, s.35-6) öngörülmektedir. Ayrıca kentsel alanlarda endüstriyel atıklara ve kirli enerji kaynaklarının kullanımına bağlı hava kirliliğinden her yıl ölen insan sayısı $(1,2$ milyon) da çevresel koşulların düzenlenmesiyle azaltılabilir (WHO, 2010a).

Hava kirliliğii, 2012 yılında küresel ölümlerin sekizde birinden sorumludur ve günümüzdeki en büyük çevre sağlığ 1 riski olarak kabul edilmektedir (WHO, 2012). Hava kirliliğinin ise en önemli nedenlerinden biri kömür enerjisidir. Avrupa’da elektrik üretiminin dörtte birinin (HEAL, 2013) ABD'de ise \%39'unun (EIA, 2014) kaynağı olan kömür küresel çevre kirliliğini önemli düzeyde artırmakta, üretiminden tüketimine dek her aşamasında solunum yolları hastalıklarına, kalp ve damar hastalıklarına, sinir sistemi hastalıklarına yol açmakta, iklim değişimini ve küresel ısınmayı hızlandırmaktadır (Lockwood vd., 2009; WHO, 2014g). Bununla birlikte enerji alanında özelleştirme nedeniyle kapitalist işletmeler daha pahalı ama daha temiz enerji kaynakları yerine ucuz kömür enerjisini tercih etmektedirler, bu nedenle önümüzdeki yıllarda da kömürün dünyanın enerji ihtiyacının en az dörtte birini karşılamaya devam edeceği tahmin edilmektedir (Anderson, 2006). Bunun en önemli göstergelerinden biri, çevre kirliliğini önleme konusunda lider kuruluşlar arasında sayılan Dünya Bankası’nın kömürle ilgili verdiği kredi miktarının 2007 sonrasında 2,5 kat artmış olması, diğer bir deyişle kömür yakıtlı enerjileri finanse etmesidir (Mooney, 2014, s.172).

Gelişmiş ülkelerde endüstrinin neden olduğu çevre kirliliği, sağlık üzerindeki etkisi nedeniyle ciddi bir sorun haline geldiğinde düşünülen çözüm zehirli kimyasalların azgelişmiş ülkelere satışı olmuştur.
1991 yılında Dünya Bankası Başkan Yardımcısı ve Ekonomi Direktörü olan Lawrance Summers, meslektaşlarına yazdığı ve kamuya sızdırılan bir notta (Enwegbara, 2001) zehirli atıkları düşük gelirli ülkelere satmanın ardındaki ekonomik mantığın 'kusursuz' olduğunu belirtmekte ve bu satışlarda ulaşım maliyetinin çok yüksek olmasından ötürü üzüntü duyduğunu eklemektedir. Summers’a göre kansere neden olan aracıların gerçekten kansere neden olma oranı gelişmiş ülkelerde azgelişmiş ülkelere göre daha fazla olacaktır, çünkü atıkların satılacağı azgelişmiş ülkelerde beş yaş altı ölüm oranı binde 200 civarındadır, yani hayatta kalıp kansere yakalanacak olanların sayısı zaten azdır (Enwegbara, 2001; Johnson vd., 2007). Bu not ortaya çıkınca yaşanan tartışmalar üzerine zehirli kimyasal atıkların gelişmiş ülkelerden azgelişmiş ülkelere satışı 1994 Basel Konvansiyonu ile yasaklanmıştır, ancak kirlilik yaratan endüstriyel işletmelerin azgelişmiş ülkelere aktarılması devam etmektedir (Johnson vd., 2007, s.397). Üstelik kat1 atıkların azgelişmiş ülkelere satışı hâlâ tartışılmakta, azgelişmiş ülkelerin bu ticaretle elde edecekleri finansmanın açlık, yetersiz beslenme ve temiz su ve kanalizasyona erişim gibi soruların çözümünde, hatta 'çevre koşullarını iyileştirmek amacıyla' kullanılabileceği savunulmaktadır (Johnson vd., 2007, s.408).

Endüstriyel işletmeler ekonomik çıkarlarını korumak amacıyla çevre ve sağlık üzerindeki zararlı etkilerini ortaya koyan bilimsel çalışmaları ve bilim insanları$\mathrm{n} ı$ hedef alabilmektedirler. Örneğin A.B.D.de asbest araştırmaları konusunda önde gelen araştırmacılardan biri olan Irving Selikoff asbestin insan sağlığına zararlı olduğunu ortaya koyduğunda "tıbbi ehliyete sahip olmamakla" suçlanmış, saygınlığını zedeleyecek saldırılarla karşılaşmış, daha sonra bu saldırılardaki iddiaların asbest endüstrisi tarafından düzenlenmiş asılsız iddialar olduğu ortaya konmuştur (McCulloch ve Tweedale, s.2007). Selikoff işçi ve toplum sağlığ1 konusunda bilimin tek başına yeterli olmadığını, sorunun bilimsel olduğu kadar politik ve toplumsal bir yanı olduğunu ifade ederken, endüstriyel firmalara danışmanlık yapan bir başka bilim insanı asbest kadar değerli bir materyal için bazı ölümleri göze almanın gerekli ve kaçınılmaz olduğunu ileri sürerek endüstrinin çıkarlarını korumaya devam etmiştir (Terzi, 2013, s.35). Benzer şekilde Benjamin Santer 1995 yllında araştırmasının sonucunda küresel ısınmanın başladığını ve bu durumun iklimin sera gazlarına ve aerosollere verdiği yanıt olduğunu, yani küresel ısın- 
maya insan davranışının neden olduğunu yazdığında Wall Street Journal araştırma bulgularını tahrif etmekle ve toplumu aldatmakla suçlanmış (The Wall Street Journal, 1996) ve Santer'in 29 meslektaşının imzaladığı savunma mektubunun sadece bir kısmını yayınlamıştır (Moyers, 2014). Takeshi Hirayama, pasif sigara içiciliğinin akciğer kanseri riskini artırdığına dair bulgularını yayınladığında, tütün endüstrisi, bulguların doğru olduğunu bildiği halde toplumun \%80'ine ulaşan milyar dolarlık bir reklam kampanyasıyla bu çalışmayı çürütmeye çalışmıştır (Ong ve Glantz, 2000). Türkiyede de durum çok farklı değildir. 1995-2004 yılları arasındaki ölümlerin \%32'sinin kansere bağlı olduğu Dilovası'nda on yıldan uzun süre yaşayanların kansere yakalanma riski, daha kısa süre yaşayanlardan 4,4 kat fazlaydı ve hava kirliliği, olması gereken değerin 3,5 kat fazlasıydı (Terzi, 2013, s.23). 2010 yılında Onur Hamzaoğlu, bölgede yürüttüğ̈̈ bir araştırmanın, insanların bölgedeki kirlilikten henüz anne karnındayken etkilenmeye başladıkları gösteren bulgularını toplumla paylaştığında henüz sonlanmamış bir araştırmanın verilerini kullanmakla ve 'yalancılık'la suçlanmış ve halkta korku ve panik yarattığı iddiasıyla mahkemeye verilmiştir (Terzi, 2013, s.25-38).

\section{Sağlıksız Kentleşme, Sağlıksız Beslenme}

Kentlerde hava kirliliği, kalabalık barınma koşulları, yetersiz gıda güvenliği kalp ve şeker hastalıklarına, yüksek tansiyona, obeziteye, diareye, tüberküloza neden olmakta, ayrıca kırsal alanlara oranla yaralanma, şiddet, trafik kazası, zihin sağlığı sorunları, madde bağımlılığı, intihar, cinayet ve savaş nedeniyle ölüm riski yükselmektedir (WHO, 2010b; Zwi vd., 1996). Üstelik dünyadaki kent nüfusunun üçte biri gecekondularda yaşamaktadır ve gecekonduda yaşayan bir çocuğun beş yaş altında ölme riski, daha iyi koşullarda yaşayan çocuklara oranla dört kat daha fazladır (WHO, 2010b). Plansız kentleşmeye ve yetersiz altyapıya bağlı olarak kirli su ve yetersiz kanalizasyon her yıl diareye bağlı 1.8 milyon ölümün nedenidir ve beş yaş altı çocuklarda bu nedenlere bağlı ölüm oranı, AIDS'in ve sitmanın neden olduğu ölümlerin toplamından daha fazladır (WHO, 2014h).

Kentlerin dezavantajlarının azaltılması yönünde çabalar, DSÖ’nün 1986 yılında "Sağlıklı Kentler" projesini geliştirmesine neden olmuş, günümüzde dünya genelinde binden fazla kent bu projeye dahil olmuştur. Ancak DSÖ özellikle azgelişmiş ülkelerde kaynak sıkıntısı, koordinasyon ve istikrar eksikliği gibi nedenlerle ilerlemenin sınırlı olduğunu belirtmektedir (WHO 2014i). Türkiye'de bu çalışmalar 2004 yılında kurulan Sağlıklı Kentler Birliği (www.skb.org.tr) çerçevesinde organize edilse de yerel yönetimler ve gönüllü çalışanlar çerçevesinde yürütülen bu çabalar kentsel alanların kullanımına ilişkin bir yaptırıma sahip değildir.

Kentsel alanların toplum sağlığından çok kâr gözetilerek düzenlenmesinin bir sonucu da yeşil alanların eksikliğidir. Kent planlamacıları tarafından yapılan hesaplar kentsel alanlarda her semtte (eve en fazla 800 metre uzaklıkta) en az beş, her bölgede (eve en fazla 1600 metre uzaklıkta) en az 10, kent genelinde (eve en fazla 3200 metre uzaklıkta) en az 60 hektar yeşil alan bulunması gerektiğini (Herzele ve Wiedeman, 2003) ortaya koymaktadır. DSÖ'ye göre kentlerde kişi başına en az 9, ideal olarak ise 10 ila 15 metre kare yeşil alan bulunmalıdır (UNDP, 2014a). Kentlerde yeşil alanlar biyolojik çeşitliliği koruyacak, yüksek enerji kullanımı nedeniyle yapay olarak yükselen hava s1caklığını, gürültü kirliliğini ve stres düzeyini azaltacaktır (Haq, 2011, s.602-3). Ancak azgelişmiş ülkelerin çoğunda yüksek kentleşme oranlarına rağmen plansız kentleşme, özellikle kentlerdeki düşük gelirli bölgelerde yeşil alanların eksikliğine yol açmaktadır. Örneğin İstanbul'da kişi başına düşen yeşil alan miktarı, resmi rakamlara göre 6.05 metrekaredir (İBB, 2010). Yeşil alan eksikliği, fiziksel etkinliği de kısıtlamakta ve bu durum önceden hazırlanmış ve işlenmiş gıdaların ağırlıklı olduğu, yağ, şeker ve tuz oranı yüksek olan 'hızlı ve ucuz' kentli beslenme tarzıyla birleştiğinde kalp hastalığı ve obezite başta olmak üzere çeşitli hastalıklara yok açmaktadır (WHF, 2012).

Obezite giderek daha ciddi bir sorun haline gelmektedir, dünya nüfusunun yaklaşık üçte ikisinin (\%65) yaşadığ 1 ülkelerde fazla kilolu ya da obez olmanın yol açtığı ölüm oranı, düşük kilolu olmanın yol açtığı ölüm oranından yüksektir (WHO, 2014j). Obetizenin 1980 'lerin sonundan itibaren bir salgin haline gelmesi (Bray, 2011, s.370) şaşırtıcı değildir. Bu salgının yayılmasında özellikle düşük gelirli kentsel toplulukların ucuz endüstriyel ürünler ve hazır yiyeceklerle (fastfood) beslenmelerinin ve neoliberalizmin sistematik aşırı üretim ve aşırı tüketimi vurgulamasının (Guthman, 2011, s.227) etkili olduğu belirtilmektedir. Ucuz gıdalar, işçilerin daha düşük ücretlerle yaşamlarını sürdürebilmelerini sağladığı için kapitalizmin ilk dö- 
nemlerinden beri önemlidir (Albritton, 2011, s. 205). Ayrıca hazır gıda endüstrisinin kapitalist işletmeleri sağlıklı beslenme yolunda atılan adımların önünü kesmektedir. Örneğin DSÖ ve Gıda ve Tarım Örgütü 2003 yılında günlük kalori alımındaki şeker oranının \%10’u geçmemesi gerektiğini belirttikleri bir kılavuz çıkarmış, ancak şeker endüstrisinin siyasetçiler üzerindeki baskıları nedeniyle finansmanlarını yitirme tehdidiyle karşılaşmış ve bu maddeyi kılavuzdan çıkarmışlardır (Dyer, 2003'ten aktaran Albritton, 2011, s.211). A.B.D.de gıda satışının yarısından fazlasını, dünya genelinde de $\% 15$ 'ini on büyük gıda şirketi yürütmektedir (Stuckler ve Nestle, 2012). Küresel gıda pazarının üçte birinden fazlasını elinde bulunduran büyük üretici firmaların ürettiği bütün ürünlerin dörtte üçü işlenmiş gıdalardır (Alfranca vd., 2003). $\mathrm{Bu}$ firmaların gücü ulusal politikaları etkilemektedir, örneğin İngiltere'de piyasada işlenmiş hazır gida satan büyük firmalar Sağlık Bakanlığı tarafından beslenmeyle ilgili hastalıklara yönelik politika hazırlamak üzere davet edilmiş (Daily Mail, 2010), bu firmaların politikaları ile kamu faydası arasındaki çatışma dikkate alınmamıştır. Gıda firmalarının kontrolsüz gücünün bir sonucu da obezitenin azgelişmiş ülkelere yayılmasıdır. Başlangıçta yüksek gelirli ülkelerin sorunu olarak algılanan obezite artık orta ve düşük gelirli ülkelerde, özellikle kentsel alanlarda artmakta ve azgelişmiş ülkelerin çocuklarında obezitenin gelişmiş ülkelerdeki çocuklardan \%30 daha fazla olduğu bilinmektedir (WHO, 2014j). Maliyeti azaltılip verimliliği artırılmış ucuz gıdaların yoksulları etkilemeye devam edeceği açıktır, örneğin ucuz ve sık tüketilen gıdalardan olan endüstriyel piliç ve yoğurt, üretim s1rasındaki endüstriyel amaçlı müdahaleler nedeniyle beslenmeye bağlı hastalık yükünü açıklamada ilk iki sırayı almaktadır (Dizdar, 2013, s.191).

Dünyada beslenme açısından iki büyük sorun açlık ve obezitedir, ancak açlık, obezite gibi "salgın hastalık" statüsüne sahip değildir. Bu durumun nedenleri arasında tamamen önlenebilir nitelikte olan açlığın adalet ve ahlak açısından hiçbir şekilde açıklanamaması (Albritton, 2011, s.213) ve ağırlıkla gelişmiş ülkelerde görülen obezitenin tedavi edilebilecek bir hastalık olarak sunulabilmesidir. Başka bir deyişle, etrafımızı çevreleyen çok sayıdaki "riskten" biri olarak görülebilen obezite, sağllk sistemi içinde tedavi edilebilir bir niteliğe, dolayısıyla sağlık hizmeti tüketimini artırma kapasitesine sahiptir. Günümüzde bireyler çevre kirliliği, sürekli ortaya çıkan yeni virüsler ve salgınlar, gıdalardaki kimyasal katkı maddeleri, kullanılan ilaçların yan etkileri, işsizlik, çalışma yaşamına bağlı stres gibi riskler ve iletişim teknolojileri nedeniyle oluşan bilgi kirliliği karşısında korku ve belirsizlik içindedir (Beck, 1992; Delibaş, 2013). Modern toplumun merkeze sağllğı koyan bir 'risk toplumu' olduğunu ileri süren Beck (1992, s.83) sağlığ1 tehdit eden risk faktörlerini üretenlerin de, bu risklerden korunmak için satın alacağımız ürünleri üretenlerin de sağlığa yönelik riskleri birer ekonomik piyasa faktörü haline getirdiğine dikkat çeker. Neoliberal ideoloji, sağlığı belirleyen toplumsal, ekonomik ve çevresel faktörleri gizleyip bireysel yaşam tarzı faktörlerini vurgulayarak sağlıksızlığın sorumluluğunu bireye yüklemektedir (Crawford, 1984). Bireyler, hastalıklara kişisel davranışlarının neden olduğunu düşünmeye sevk edilmektedir, oysa obezite, hareketsiz yaşam tarzı, veya sınıfsal bir davranış olduğu açıkça ortaya konmuş olan (Stellman ve Resnicow, 1997) tütün kullanımı gibi faktörler bireyin kontrolünün ötesindeki yapıların sonucudurlar. Sağlıktan bireyi sorumlu tutan bu bakış açısına göre bireyler etraflarını saran risklerin farkında olmalı ve kendilerini korumak için besin takviyeleri, hava veya su filtreleri satın almalı, yeşil alanlar eksikse ücretli spor salonlarında egzersiz yapmal, gida endüstrisinin sattığı yağlı, tuzlu ve şekerli gidalardan kaçınmak için erişimi zor ve pahalı olsa da organik tarım ürünlerine yönelmeli ve hasta olmasalar dahi düzenli sağlık kontrolleri yaptırmalıdırlar. Açıkça görülmektedir ki risklere karşı alınacak önlemler yine endüstri ile ilişkilidir ve bireyin kendini korumak için yapabileceği tek şey tüketimini artırmaktır.

Kısacası neoliberal politikalar çerçevesinde kamusal yaşamda toplumu koruyan devlet düzenlemelerinin ortadan kaldırılması ya da zayıflatılması, çalışma ve yaşama koşullarının kötüleşmesine, buna bağlı olarak toplumun dezavantajlı kesimlerinin ölüm ve hastalık oranlarının artmasına neden olmaktadır. Bu noktada sosyal refah devletinde risklere karşı devlet korumasına sahip olan ancak artık bunu kaybetmiş olan ve bu nedenle hastalanan kitleler için tedavi hizmetleri ve sağlık sistemleri hazır beklemektedir, ancak neoliberal ideoloji sağlığı ekonominin yeni gücü olarak gördüğü için sağlık sistemleri de neoliberal ilkere uyacak şekilde büyük bir dönüşüm geçirmiştir. 


\section{Neoliberalizmin Sağlık Sistemleri Üzerindeki Etkileri}

Neoliberal ideolojinin sağlık politikaları üzerindeki etkileri dört maddede değerlendirilebilir. Bunlardan ilki sağlık bakımında kamu harcamalarının azaltılması ve sağlık hizmetlerinin özelleştirilmesidir ve bu, her özelleştirme sürecinde olduğu gibi öncesinde kamu hizmetlerinin tasfiyesini veya zayıflatılmasını gerektirir. İkincisi sağlık profesyonellerinin azgelişmiş ülkelerden gelişmiş ülkelere, tıbbi donanımın ise gelişmiş ülkelerden azgelişmiş ülkelere doğru tam hareketliliğinin, yani hem hizmetlerin hem de malların serbest dolaşımının sağlanmasıdır. Üçüncüsü, sağlığın sosyal belirleyicilerinin, koruyucu sağlığın ve kamu sağlığının merkezde olduğu sosyal sağlık modelinin terkedilerek biyomedikal sağlık modeline geri dönülmesidir. Sağlığın biyomedikal modeli Kartezyen zihin-beden ayrımına dayanan, hastayı bozuk bir organa indirgeyen, iyileşmenin sadece tıbbi ve teknolojik müdahalelerle gerçekleşeceğini savunan, sağlığın sosyal, ekonomik ve politik yönlerini göz ardı eden, bu yönüyle de sağlığın metalaşmasına zemin hazırlayan bir modeldir. Son madde ise ulusal sağlık sistemlerini piyasa tipi sağlık sistemlerine dönüştürecek reformların gerçekleştirilmesi şeklinde özetlenebilir. Bu etkiler sosyal refah devleti aracılığıyla sağlık alanında elde edilmiş olan kazanımların yitirilmeye başlanmasına yol açmıştır.

DSÖ 1960'lar ve 1970'ler boyunca sağlık sorunlarının ardında yatan sosyal ve ekonomik faktörlere odaklanmış, sağllğın iyileştirilmesi yönünde kendi işlevinin politik öncülük olduğunu kabul etmiştir (Aksakoğlu, 2003, s.2). Bu ortamın etkisiyle yayınlanan Alma Ata Bildirgesi’nde dünyadaki tüm insanların sağlıklarını korumak ve iyileştirmek için en kısa zamanda sosyal eşitliğin, ücretsiz ve yeterli sağlık hizmetlerinin sağlanması gerektiği vurgulanmıştır (WHO, 1978). Bu bildiri, hastane merkezli biyomedikal sağllk modeline yönelik en güçlü alternatif olarak görülmüştür, ancak neoliberal politikaların uygulanmaya başlanmasıyla birlikte bu eleştirel dönemin sona erdiği ve DSÖ'nün kendisinin de neoliberal ideolojiyi yeniden ürettiği vurgulanmaktadir (Navarro, 2008, s.152-3; Mooney, 2014, s. 53-54). Bu durum kısmen DSÖ'nün IMF ve Dünya Bankası karşısındaki gücünü yitirmesinin bir sonucu olarak görülebilir. 1970'lerin sonundan itibaren İngiltere'de Thatcher, A.B.D.de Reagan ile birlikte iktidara gelen Yeni Sağ hükümetler serbestleşme, deregülasyon ve özelleştirme yanlısı politikalar izleme- ye başlayınca bağımsızlığını 1980'lerde kazanmış çok sayıda devlet fon ihtiyacı nedeniyle IMF ve Dünya Bankası'nın yapısal uyum programlarını kabul etmek zorunda kalmıș, böylece bu iki küresel kurumun azgelişmiş ülkelerin politikalarının şekillenmesinde payı artmıştır. Yapısal uyum programlarının sağlık üzerindeki etkileri hakkında yapılmış 76 çalışmanın sadece \%8'i olumlu sonuçlar ortaya koymuştur (Breman ve Shelton, 2001). 1980'lerin ortasindan itibaren Dünya Bankası sağlık alanının piyasalaştırılması gerektiği yönünde baskı yapmaya başladığında DSÖ, Dünya Bankası'nın finansal kaynakları ve ideolojik ağırlığı nedeniyle gücünü kaybetmiş, bütçesi dondurulduğu için daha fazla ödün vermeye başlamıştır (Lister ve Labonte, 2009, s. 202). DSÖ’nün 2000 yılındaki Dünya Sağlık Raporu'nu hazırlayan ekibin büyük çoğunluğunun Dünya Bankası'nda, OECD'de, özel sağlık örgütlerinde, özel sigorta şirketlerinde ve üniversitelerde çalışanlardan olması, sadece ikisinin çeşitli ülkelerin Sağlık Bakanlıklarında çalışıyor olması (Lister ve Labonte, 2009, s.206), DSÖ’nün neoliberalizmi yeniden üretme yolunu ortaya koymaktadır. Böylece Dünya Bankası, Dünya Ticaret Örgütü, OECD ve IMF gibi küresel ticarete yön veren kuruluşların baskısıyla sağlık alanının piyasalaşma süreci hız kazanmıştır. Dünya Bankası, 1993 yılında yayınladığı Dünya Kalkınma Raporu’nda azgelişmiş ülkelerde hastanelerde verilen hizmetlerde kamusal finansmanın en aza indirilmesini, diğer hizmetlerin sunumunun, finansmanının ya da her ikisinin birden özelleştirilmesini, küresel olarak bağlantılı bir sağlık sistemi kurulmasını ve en yoksul ülkelerde halk sağlığ 1 ve temel klinik hizmetler için kişi başına 12 A.B.D. doları katılım payı ödenmesini önermiştir (Lister ve Labonte, 2009, s.203).

$\mathrm{Bu}$ makroekonomik unsurların yanı sıra, Dünya Bankası'ndan araştırma fonları ve bulgularını yayınlama konusunda yoğun destek alan bir dizi politika yapıcı, teknik danışman ve akademisyen de küresel kurumlar tarafından önerilen politika reformlarını desteklemiş (Lister ve Labonte, 2009, s.206), böylece kamu hizmetlerinin verimsiz, yavaş ve kalitesiz olarak tanımlanmasında ve Yeni Kamu Yönetimi paradigmasının güçlenmesinde etkili olmuşlardır. $\mathrm{Bu}$ paradigma çerçevesinde kamu sektörü de özel sektör gibi kâr ve verimlilik amacına yönelik olarak yeniden örgütlenmiştir. Ayrıca gelişmiş ülkelerde ortalama yaşam süresinin uzaması ve tıp ve farmakoloji alanındaki gelişmeler nedeniyle yirminci yüzyılın or- 
talarına dek en önemli ölüm ve hastalık nedeni olan bulaşıcı ve akut hastalıkların yerini uzun süren ve tedavisi daha pahalı olan kronik hastalıkların alması ve bu nedenle sağlık hizmeti talebinin artması da sağlık alanındaki neoliberal reformların nedenleri arasında sayllmaktadır (Ağartan, 2007, s.45).

$\mathrm{Bu}$ nedenler çerçevesinde 1990'ların başından itibaren küresel reform paketine bağlı olarak pek çok ülkede sağlık reformları gerçekleştirilmeye başlanmış, sağlıkta reform "küresel bir salgın" haline (Klein, 1993) dönüşmüştür. Farklı ülkelerde uygulanmakla beraber birbirine son derece benzeyen bu reform paketleri ulusal sağlık sitemlerinden sosyal sigorta sistemlerine geçilmesini, sağlık hizmetlerinin sunumu ile finansmanının birbirinden ayrılmasını, hastalığı önleyici mekanizmaların ve birinci basamak hizmetlerin yaygınlaştırılarak ikinci ve üçüncü basamak hizmetlere olan talebin azaltılmasını ve piyasa mekanizmalarının daha çok kullanılmasına yönelik olarak sosyal güvenlik sistemlerinin yeniden yapılandırılmasını içermektedir (A ğartan, 2007, s.47-49). Böylece sağlık hizmetlerinin ulusal vergilerden karşılandığ sistemlerde finansman kaynağı sigorta primlerine dönüşmüş, kamunun sunduğu sağllk hizmetleri temel teminat paketleriyle sınırlandırılarak özel sigortacılık desteklenmiş, sağlık bakımı almak isteyenlerin ödemesi gereken katkı ve katılım payları belirlenmiştir. $\mathrm{Bu}$ reformlar arasındaki benzerliğin tesadüfi olmadı$\breve{g}_{1}$, neoliberal politikaların eninde sonunda tüm ulusal sağlık sistemlerini, sağlık hizmetlerinin neredeyse tamamının özel sektörün elinde olduğu, dünyadaki en pahalı ve en az kapsayıcı sağlık sistemi olarak kabul edilen A.B.D. sağllk sisteminin türevlerine dönüştüreceği öngörülmektedir (Leys, 2007, s. 104-110) ${ }^{2}$.

2 Bu çalışmanın konusu spesifik olarak Türkiye'deki uygulamalar olmamakla birlikte, Türkiye’de sağlıkta yaşanan dönüşüm sonrası sağlık hizmetlerinden duyulan memnuniyetin artması (Akdağ vd.2008) neoliberal politikalarla sağlık sistemleri arasındaki ilişki tartışılırken sıklıkla üzerinde durulan bir konu olduğu için bu duruma kısaca değinmek yararlı olacaktır. Küresel sağlık reformlarının Türkiye'deki yansımaları 1990'lar boyunca sağlık sistemini serbest piyasa koşullarına adapte etmeyi amaçlayan öneriler getirilmesi ve nihayet 2003 yllında uygulanmaya başlanan Sağlıkta Dönüşüm Programı (SDP) olmuştur. Bu programın Türkiyede sağllk hizmetlerinin sunumu açısından olumlu sonuçları olmuştur. SDP öncesinde Türkiyede sağlık sistemi yurttaşları istihdam statüsüne göre hiyerarşik olarak sıralayan, farklı sosyal güvence kurumlarının birbirinden farklı kalitede sağlık hizmeti sunduğu, bireylerin ancak kendi sağlık güvencelerinin hizmet sunduğu sağlık kurumlarına başvurabildiği ve sosyal güvence kapsamı dışındaki nüfusun sağlık hizmetlerinden faydalanamadığ (Üstündağ ve Yoltar, 2007). SDP ile birlikte bu sorunların bir
Neoliberal piyasa mantığ sadece sağlık sistemlerinin yasal yönünü değiştirmemiş, sağlıktaki işgücü piyasasını da yeniden şekillendirmiştir. Piyasa baskısı ve neoliberalizmin değerleri tarafından yönetilen sağlık kurumlarında çalışan hekimler meslekleri üzerindeki özerklik, denetim ve kontrolü yitirmeye (Ünlütürk Ulutaş, 2011, s.116-128) ve bir meslek grubu olarak zayıflamaya başlamışlardır (Candansayar, 2009; Elbek, 2013). Örneğin bu yeni çalışma düzeninin ücret üzerindeki yansıması olan performansa dayalı ödeme sistemi, doktorların beşte dördüne (\%81) göre çalışanlar arasında rekabeti, dörtte üçüne (\%75) göre çalışma stresini artırmakta ve yarısından çoğuna (\%56) göre mesleki dayanışmanın azalmasına neden olmaktadır (TTB, 2009, s.42,45). Bu sürecinin dışında kalan az sayıda hekim ve akademisyen, satmayan ilaçlar için reklamclık ödülleri kazanan pazarlama kampanyalarıyla yeni hastalıklar yaratarak ilaç piyasasını düzenleyen özel ilaç firmaları ile işbirliği içinde çalışmaktadır (Moynihan, 2006). Endüstri tarafından finanse edilen akademik araştırmaların bilimsel bulguları çarpıttığı, bilimi yönlendirdiği ve ambalajladığ1 ve bağımsız çalışan araştırmacılara saldırmak ve onları taciz etmek için kullanıldığına dair çok sayıda bulgu mevcuttur (Terzi, 2010). Tip profesyonellerinin piyasa mantığına göre davranmasının bir başka sonu$\mathrm{cu}$ ise doktor hasta ilişkisinin niteliğinin değişmesi, doktorların hastaları daha fazla ücret elde etmenin

kısmı çözülmüş, istihdama dayalı ayrımcılık ortadan kalkmış, hastaneler tek çatı altında toplandığı için herkes istediği sağlık kurumuna başvurabilir hale gelmiş, genel sağlık sigortası ile birlikte sağlık açısından sosyal güvence kapsamı genişlemiş, yeşil kartlılara sağlanan hizmetler artırılmış ve hasta hakları konusunda ilerleme kaydedilmiştir. Dolayısıyla neoliberal politikalar çerçevesinde gerçekleştirilen bazı uygulamaların "sağlık hizmetlerinin tüketimini teşvik ederek "piyasa" yaratmak uğruna da olsa, düne kadar sağlığa ulaşmakta sorun yaşayan insanların sağlığa erişimini kolaylaştırdığı" (Elbek, 2009:10) gözden kaçırılmamalıdır. Bu olumlu yönlerinin yanında Türkiye’nin mevcut sağlık sistemi sağlık hizmetlerinden faydalanmak için prim ödemeleri ile katkı ve katılım payı ödemelerini zorunlu kılan bir sistemdir ve 2003 yllından beri hem katkı ve katılım payları artış göstermekte hem de temel teminat paketi daraltılarak bireyler özel sağlık sigortalarına yönlendirilmektedirler. Mevcut haliyle Türkiyede sağlık sisteminin asıl işlevinin kamu kaynaklarının özel sektöre aktarılmasını sağlamak olduğu (Yavuz, 2010:101) dikkate alınırsa uzun vadede Türkiye'deki sağlık sisteminin de Leys'in (2007:110) öngördügü gibi A.B.D.nin sağllk sistemine benzeme ihtimali yüksek görünmektedir. Dolayısıyla sağlık hizmetlerinde SDP sonrası yaşanan iyileşmenin neoliberal politikaların kamu faydasını gözetmesinden ziyade Türkiye'de önceki dönemlerde sağlık hizmetlerinin kapsayıcı ve eşitlikçi bir şekilde sunulamamasına bağlı olduğu söylenebilir. 
yolu olarak görmeleri ve hastaların doktorlara giderek daha az güven duyar hale gelmeleridir. Elbette bu durumun piyasalaşmış bir sağlık sistemi açısından bir sakıncası yoktur, çünkü doktora daha az güven duyan hasta/müşteri daha fazla sayıda doktor görüşü almak üzere farklı sağlık kurumlarına başvuracak ve daha fazla sağlık harcaması yapacaktır. Doktor ve hasta arasındaki ilişkinin metalaşması "insani değerlerle piyasa fiyatlarının eşitlendiği bir düzen” (Keshavjee, 2004) yaratmaktadır.

\section{Neoliberalizmin Sağlık Üzerindeki Etki- lerinin Kesişim Noktası: Eşitsizlik}

Amartya Sen ortalama yaşam sürelerinin yalnızca halk sağllğını önceleyen ülkelerde uzatılabildiğini göstermiş ve sağlık alanında önemli olanın yapılan harcamanın miktarı değil, nereye harcandığı olduğunu belirtmiştir (Sen, 2001). Gelişmiş ülkelerin ulusal refah düzeylerini, sağlığa yaptıkları harcamaları ve hastalanma ve ölüm oranlarını karşılaştıran Wilkinson (1996) zenginliğin ve sağlık harcamalarının toplum sağlığı ve ortalama yaşam beklentisi üzerinde ancak bir dereceye kadar etkili olduğunu göstermiştir. Gelişmiş ülkeler arasında en iyi sağlığa sahip olanların en zengin ülkeler değil, en eşitlikçi olan ülkeler olduğunu gösteren Wilkinson’a (1996) göre en sağlıklı ülkeler toplumsal bağlllık ve dayanışmanın yüksek, baskının az olduğu ve sosyal adaletin sağlandığı ülkelerdir. Bir toplumda eşitsizlik ne kadar fazlaysa birlik ve dayanışma da o kadar azdır ve mağdur insanlara karşı duyarlı olmayan toplumlarda eşitsizliğin sağlık üzerindeki olumsuz etkileri de daha fazladır (Mooney, 2014, s.68). Sağlık hizmetlerinin neredeyse tamamının özel ödemeye dayalı hale dönüşeceği yönündeki öngörü özellikle önemlidir çünkü böyle bir sistem zengin ve sağlıklı insanların başkalarının benzer standartlara sahip olmaları için herhangi bir destek vermeden yüksek fiyatlı özel sağlık hizmetlerini satın almalarını sağlar (Evans, 1997, s.427). Halbuki İngiltere'de ulusal sağlık sisteminin kurucularından olan Bevan (1952) bundan altmış üç yll önce önlenebilir acıların bütün toplumlar için bir kara leke oldugunu belirtmiş, yurttaşlar hasta olduklarında sadece kendilerinin için değil, herkesin tıbbın sunabildiği en iyi hizmete ulaşabileceğini bilirlerse toplumun daha erdemli, huzurlu ve ruhsal olarak daha sağliklı olacağını savunmuştur. Şu halde sosyal refah devletinin zayıflamasının sağlık üzerindeki etkisi sadece maddi kaynakların topluma etkin dağıtılamaması değildir.
Neoliberalizm eşitsizlikleri derinleştirerek toplumun dayanışma ve sosyal adalet duygularını zedelemektedir. Neoliberal devletler tarafindan korumasız bırakılan toplum üyelerinin küresel piyasadaki şirketler için ya ucuz işgücü ya da harcamaları körüklenen tüketiciler haline dönüşmektedir. Çalışma yaşamında, kentsel düzenlemelerde, çevre, gıda ve tarım güvenliğinde deregülasyon toplum sağlığını bozmakta, bozulan sağlık için sağlık sistemi içine girenler de kendilerini özel sağlık, sigorta ve ilaç firmalarının arasında bulmaktadır.

\section{Sonuç}

Mevcut literatürdeki bulgular göstermektedir ki neoliberal politikaların sağlık üzerindeki etkileri sadece sağlık politikaları ya da sağlık sistemleri ile ilişkili değildir. Devletin toplum sağlığını kendi sorumluluk ve rol alanından çıkarmasıyla birlikte toplum sağlığ ve kamu hizmeti arasındaki ilișkinin çözülmesi farkı boyutlar üzerinden sağllğ etkilemektedir. Bu boyutlar istihdam düzeyi ve çalışma koşulları, çevre, tarım ve gida güvenliği, kentleşme ve beslenme, sağlık sistemlerindeki dönüşüm ve sosyal adaletin zayıflaması şeklinde özetlenebilir.

Neoliberalizmin sağlık sistemleri üzerindeki etkisi son derece önemli olmakla birlikte, toplum sağllğ üzerindeki etkisi bununla sınırlı olmayıp çok daha geniş bir alanda devletin düzenleyici ve kontrol edici rolünün zayıflamasıyla ilişkili görünmektedir. Neoliberal politikaların çalışma, kentleşme, çevre, tarım, beslenme ve sağlık ile ilgili yasaları esnekleştirmesi, sağlığa doğrudan ya da dolaylı olarak zarar verecek şekilde çalışan endüstriyel işletmeler üzerinde devlet denetimini ve yaptırım gücünü zayıflatması anlamına gelmekte ve toplum sağlığı üzerinde olumsuz etkiler yaratmaktadır. İşsizlik, güvencesizlik, örgütsüzlük, ağır çalışma koşulları, iş üzerinde özerklik ve kontrole sahip olamama, düşük ücretlerle çalışma, sağllksız kentlerde hava ve gürültü kirliliği içinde yaşama, yetersiz ve kötü beslenme gibi faktörlerin insan sağlığına zarar verdiği pek çok çalışmayla ortaya konmuştur. Her ne kadar neoliberal politikalar sağlığın sosyal belirleyicilerini görmezden gelerek hastalıklardan bireysel yaşam koşullarını sorumlu tutsalar da çalışma ve yaşama koşulları üzerindeki bozucu etkisi nedeniyle hastalıkları neoliberalizmin kendisinin yaratmakta ve artırmakta olduğu söylenebilir. Toplum sağlığına zarar verecek şekilde işleyen kapitalist işlet- 
melerin üzerinde devlet denetiminin zayıflaması son derece kritik bir öneme sahiptir, çünkü kapitalist işletmeler tanım itibarıyla kârlarını maksimize etmeye çalışan işletmelerdir ve insan veya toplum sağlığından sorumlu değildirler. Sağlığın sosyal belirleyicilerinin etkisi dikkate alındığında, bireylerin sağlıklarını kişisel davranışlarla korumayacakları da belirginleşmektedir. Bu durumda sistem karşısında savunmasız ve dezavantajlı olanların sağlıkları ancak toplum ve devlet tarafından korunabilir. Sağlık, toplumda eşitsiz bir şekilde dağıtılabilecek bir 'kıt kaynak' değil, herkesin kendiliğinden sahip olduğu, elinden alınamayacak olan bir haktır ve korunması için toplum faydasını özel şirketlerin faydasından ve sağlığı kârdan daha değerli görecek toplumcu bir bakış açısı gereklidir.

Kısacası neoliberalizmin sağlık üzerindeki bozucu etkisi sadece sağlık sistemlerinin dönüşümünden kaynaklanmamaktadır. Bu açıdan devlet, ekonomi politikaları ve sağlık arasındaki ilişkiye dair yapılacak değerlendirmelerde sağlik hizmetlerinin sunumuna ve finansmanına odaklanılması ve toplum sağlığının iyileştirilmesinde sağlık sistemlerinin ve sağllk politikalarının rolünün fazla vurgulanması sağlığı etkileyen diğer faktörleri gözden kaçırmaya neden olabilir. Toplum sağlığının iyileştirilmesi sosyal adaleti ve eşitliği merkeze alarak hareket edilmesine, sadece sağlık politikalarına değil, sağlığı etkileyen ekonomik ve sosyal belirleyicilere de odaklanılmasina ve toplum sağllğı üzerinde bozucu etkisi olan eylem ve süreçlerin devlet tarafından kontrol ve denetim altında tutulmasına bağlıdır.

\section{Kaynakça}

Ağartan, T. (2007). Sağlıkta Reform Salgını. N. Üstündağ, T. Ağartan ve Ç. Yoltar (Ed.), Avrupa'da ve Türkiye'de Sağlık Politikaları içinde (s.37-54). İstanbul: İletişim.

Akdağ, R., Aydın, S. ve Demirel, H. (Ed.). (2008). İlerleme Raporu: Sağlıkta Dönüşüm Programı. Ankara: T.C. Sağlık Bakanlığı (Yayın no.749).

Aksakoğlu, G. (2003). Dünya Sağlık Örgütü ve Sağlık Politikalarında Değişim. Sol, 199, 41-5.
Albritton, R. (2011). Obezite ile açlık arasında: Kapitalist gıda endüstrisi. L. Panitch ve C. Leys (Ed.), Kapitalizm: Sağlık Sağlısızlık Semptomları içinde (s.205218). Çeviren: Umut Haskan. İstanbul: Yordam.

Alfranca, O. , Rama, R., Tunzelmann, N. (2003). Technological fields and concentration of innovation among food and beverage multinationals. International Food and Agribusiness Management Review, 5(2) http://www.ifama.org/files/rama.PDF (Erişim: 10.12.2014)

Anderson., J.W. (2006). Coal. Dirty Cheap Energy. W.E. Oates (Ed), The RFF Reader in Environmental and Resource Policy içinde (s.181-3). 2nd Edt., Washington: RFF.

Arslan, E. ve Durukanoğlu, Ç. (2008). Tuzla Tersaneler Bölgesi Gerçeği. Metalurji.150, 27- 30. www. metalurji.org.tr/dergi/dergi150/d150_2730.pdf (Erişim: 08.10.2010).

Aslan, D. ve Şengelen, M. (2010). Farkl Boyutlarıyla Genetiği Değisştirilmiş Organizmalar. Ankara: Ankara Tabip Odası.

Aydın, U, Gökçek Karaca, N., Canbey Özgüler, V. ve Karaca, E. (2013). İş Sağlığı Ve Güvenliği Eğitiminin İş Kazaları Ve Meslek Hastalıklarının Önlenmesindeki Rolü. Çimento Endüstrisi İşverenleri Sendikası Dergisi, 27(4), 24-45.

Bartley, M. (1994). Unemployment and ill health: understanding the relationship. Journal of Epidemio$\log y$ \& Community Health, 48(4), 333-7.

Beaglehole, R. ve Bonita, R. (1997). Public Health at the Crossroads: Achievements and Prospects. Cambridge: Cambridge University.

Beck U. (1992). Risk Society: Towards a new modernity. London: Sage.

Bernstein, R. S., Meurer, L. N., Plumb, E. J. ve Jackson, J.L. (2015) Diabetes and Hypertension Prevalence in Homeless Adults in the United States: A Systematic Review and Meta-Analysis. American Journal of Public Health, 105(2), 46-60. 
Bevan, A. (1952).In Place of Fear A Free Health Service. http://www.sochealth.co.uk/resources/national-health-service/the-sma-and-thefoundation-of-the-national-health-service-drleslie-hilliard-1980/aneurin-bevan-and-thefoundation-of-the-nhs/in-place-of-fear-a-freehealth-service-1952/ (Erişim: 17.11.2014)

Böckerman, P. ve Ilmakunnas, P. (2009). Unemployment and self-assessed health: evidence from panel data. Health Economics, 18(2), 161-179.

Braveman, P. (2006). Health disparities and health equity: concepts and measurement. Annual Review of Public Health, 27, 167-94.

Bray, G.A. (2011). A Guide to Obesity and the Metabolic Syndrome. Florida: CRC.

Breman, A. ve Shelton, C. (2001). Structural Adjustment and Health: A literature review of the debate, its role-players and presented empirical evidence. Commission on Macroeconomics and Health Working Paper Series No.WG6:6. Geneva: WHO.

Burgard, S. A., Brand, J.E. ve House, J.S. (2007). Toward a Better Estimation of the Effect of Job Loss on Health. Journal of Health and Social Behavior, 48(4), 369-84.

Candansayar, S. (2009). Taşeron Bilim, İşçi Doktor ve Denek Yoksul Ülkeler. Türkiye Psikiyatri Derneği Bülteni, 12(2), 6-10.

Catalano, R., Goldman-Mellor, S., Saxton, K., Margerison-Zilko, C., Subbaraman, M., LeWinn, K. ve Anderson, E. (2011) The health effects of economic decline. The Annual Review of Public Health, $32,431-450$

Classen, T.J. ve Dunn, R.A. (2012). The effect of job loss and unemployment duration on suicide risk in the United States: a new look using mass-layoffs and unemployment duration. Health Economics, 21(3), 338-50.
Crawford, R. (1984), A Cultural Account of Health: Control, Release, and the Social Body. J. McKinlay (Ed.), Issues in the Political Economy of Health Care içinde (60-103). London: Tavistock.

Cumhuriyet. (2014, 30 Ekim) 'Tehlike var' dedi kovuldu. http://www.cumhuriyet.com.tr/haber/turkiye/135853/_Tehlike_var_dedi_kovuldu.html, (Erişim: 19.12.2014).

Cylus, J., Glymour, M. M. ve Avendano, M. (2015) Health Effects of Unemployment Benefit Program Generosity. American Journal of Public Health. 105(2), 317-323.

Dahlgren, G. ve Whitehead, M. (1992). Policies And Strategies To Promote Social Equity in Health. WHO Regional Office for Europe, Kopenhagen. http://whqlibdoc.who.int/euro/-1993/EUR_ICP_ RPD414(2).pdf (Erişim 11.07.2011)

Daily Mail. (2010, 13 Kasım). McDonald's, KFC and Pepsi to help write government policy on obesity and diet-related disease (http://www.dailymail. co.uk/news/article-1329395/McDonalds-KFCPepsi-help-set-government-health-policy-obesity. html) (Erişim: 10.12.2014).

Delibaş, K. (2013). Sağlığa ilişkin korkular: güven erozyonu bağlamında sağlık korkularını anlamlandırmak. Osman Elbek (Ed). Kapitalizm Sağlığa Zararlıdır içinde (s.101-112). İstanbul: Hayy.

Deniz, K. ve Soysal, A. (2013). Genetiği Değiştirilmiş Organizmalar. Ankara: Halk Sağlığı Uzmanları Derneği. http://halksagligiokulu.org/anasayfa/ components/com_booklibrary/ebooks/GDO_ HASUDER\%202013.pdf (Erişim: 10.12.2014)

DİSK (2014). Kamu İstihdam Bülteni. http://www. genel-is.org.tr/wp-content/uploads/2014/08/RAPOR.pdf (Erişim: (Erişim: 12.01.2015).

Dizdar, Y. (2013). Yemezler: Bilimsel Verilerle GidaHastalık İlişkisi. İstanbul: Hayy. 
Dussault, G. ve Sheiham, A. (1982). Medical Theories and Professional Development. Social Science and Medicine, 16(15), 1405-12.

EIA (U.S. Energy Information and Administration). (2014). Anaysis \& Projections. http://www.eia.gov/ electricity/monthly/ (Erişim: 12.01.2015).

Elbek, O. (2009). Sağlikta dönüşüm ve sol siyaset. Birikim. 246, 68-78.

Elbek, O. (2013). He-Kimliğin Dönüşümü. O. Elbek (Ed.), Kapitalizm Sağhı̆a Zararlıdır içinde (s.219233). İstanbul: Hayy.

Engels, F. (1997) İngiltere'de Emekçi Sınıfın Durumu. (Çev.: Yurdakul Fincancı) Ankara: Sol. (Özgün eser 1845 tarihlidir)

Enwegbara, B. (2001). Toxic Colonialism. The Tech. 121(16), $7 . \quad$ http://tech.mit.edu/V121/N16/ col16guest.16c.html (Erişim: 09.12.2014).

Eurofound (2012), Health and well-being at work: A report based on the fifth European Working Conditions Survey, Dublin. http://eurofound.europa. eu/sites/default/files/ef_files/pubdocs/2013/02/ en/1/EF1302EN.pdf (Erişim: 10.12.2014)

Evans, B. (1997). Going for the gold: the redistributive agenda behind marketbased healthcare reform. Journal of Health Politics, Policy and Law. 22(2), 427-65.

FAO (Food and Agriculture Organization of the United Nations). (1996). An introduction to the basic concepts of food security. http://www.fao.org/docrep/013/al936e/al936e00.pdf (Erişim: 10.12.2014).

FAO (Food and Agriculture Organization of the United Nations). (2010). Global hunger declining, but still unacceptably high. http://www.fao.org/docrep/012/al390e/al390e00.pdf (Erişim: 10.12.2014).

FAO (Food and Agriculture Organization of the United Nations). (2014). State of Food Insecurity in the World. http://www.fao.org/publications/sofi/2014/ en/ (Erişim: 10.12.2014).
Ferrie, J. E., Shipley, M. J., Marmot, M. G., Stansfeld, S. ve Smith, G. D. (1995). Health effects of anticipation of job change and non-employment: longitudinal data from the Whitehall II study. British Medical Journal. 311(7015), 1264-1269. (Erişim: 19.12.2014).

Goetzel, R.Z., Anderson, D.R., Whitmer, R.W., Ozminkowski, R.J., Dunn, R.L. ve Wasserman, J. (1998). The relationship between modifiable health risks and health care expenditures: an analysis of the multi-employer HERO health risk and cost database. Journal of Occupational and Environmental Medicine, 40(10), 843-54. (Erişim: 21.01.2015).

Guthman, J. (2011). Weighing In: Obesity, Food Justice, and the Limits of Capitalism. California: University of California.

Hammarstrom, A. ve Janlert, U. (2005). An agenda for unemployment research: a challenge for public health. International Journal of Health Services, 35(4), 765-77.

Haq, S.A. (2011). Urban Green Spaces and an Integrative Approach to Sustainable Environment. Journal of Environmental Protection, 2(5), 601-608.

Harrington, J. M. (2001). Health effects of shift work and extended hours of work. Journal of Occupational and Environmental Medicine; 58(1), 68-72.

Harvey, D. (2012). Yaratıcı Yıkım Olarak Neoliberalizm. Attlim Sosyal Bilimler Dergisi. 2(2), 67-88,

HEAL (The Health and Environment Alliance). (2013). The Unpaid Health Bill: How Coal Power Plants Make Us Sick. http://www.env-health.org/ $I M G / p d f / h e a l \_r e p o r t$ the_unpaid_health_bill_ how_coal_power_plants_make_us_sick_final.pdf (Erişim: 12.01.2015).

Herzele V. ve Wiedeman, T. (2003). A Monitoring Tool for the Provision for Accessible and Attractive Green Spaces. Landscape and Urban Planning, 63(2), 109-126. 
ILO (International Labour Organization). (2011). ILO Introductory Report: Global Trends And Challenges On Occupational Safety And Health. Report of XIX World Congress on Safety and Health at Work. http://www.ilo.org/wcmsp5/groups/public/@ed protect/@protrav/@safework/documents/publication/wcms_162662.pdf (Erişim: 19.12.2014)

ILO (International Labour Organization). 2014. Global Employment Trends 2014. http://www.ilo.org/global/research/global-reports/global-employmenttrends/2014/WCMS_233936/lang--en/index.htm (Erişisim: 19.12.2014)

İBB (İstanbul Büyükşehir Belediyesi). (2010). İstatistikler. http://www.ibb.gov.tr/tr-TR/BilgiHizmetleri/Istatistikler/Documents/bldhizmetleri/2010/ parkvebahceler_mud_2004-\%202010.pdf (Erişim: 21.12.2014).

Johnson, J., Pecquet, G. ve Taylor, L. (2007). Potential Gains From Trade in Dirty Industries: Revisiting Lawrence Summers' Memo. Cato, 27(3), 397-410.

Kapusuz, N. (2008). Türkiye'de İş Kazaları ve Üç Ayrı Raporun Bize Söyledikleri. http://bianet.org/bianet/ emek/105928-turkiye-de-is-kazalari-ve-uc-ayriraporun-bize-soyledikleri--2 (Erişim: 26.10.2010).

Keshavjee, S. (2004). Medicine and money: the ethical transformation of medical practice. Medical Education, 38(3), 271-275.

Klein, R. (1993). Health care reform: the global search for Utopia. British Medical Journal. 307(6907), 752.

Laaksonen, M.; Rahkonen, O.; Martikainen, P. ve Lahelma, E. (2006). Associations of working conditions with self-rated general health ve mental health among municipal employees. International Archives of Occupational and Environmental Health. 79(3), 205-212.

Labonte, R. (1998). World Trade and Investment Agreements: Implications for Public Health. Canadian Journal of Public Health. 89(1), 10-12.

Leigh, A., Jencks, C. ve Smeeting, T.M. (2009). Health and Economic Inequality. W. Salverda, B. Nolan ve T. Smeeding (Ed.), The Oxford Handbook of Economic Inequality içinde (s.384-404). Oxford: Oxford University.
Leys, C. (2007). Piyasa ile politika arasında sağlık hizmetlerinin konumu. N. Üstündağ, T. Ağartan ve Ç. Yoltar (Ed.), Avrupa'da ve Türkiye'de Sağllk Politikaları içinde (s.95-110). İstanbul: İletişim.

Liptak, K. (2011). Is atypical typical? - Atypical employment in Central Eastern European countries. Journal for Employment and Economy in Central and Eastern Europe. (1), 1-13.

Lister, J. ve Labonte, R. (2011). Küreselleşme ve Sağlık Sistemleri Değişimi. R.Labonte, T. Schrecker, C. Packer ve V. Runnels (Ed.), Küreselleşme ve Sağlk: Süreç, Kanttlar ve Politika içinde (s.200-233). İstanbul: İnsev.

Lockwood, A.H., Welker-Hood, K., Rauch, M. ve Gottlieb, B. (2009) Coal's Assault on Human Health: A Report From Physicians For Social Responsibility. http://www.psr.org/assets/pdfs/psr-coal-fullreport. pdf (Erişim: 12.01.2015).

Marmot, M. (2004). Status Syndrome: How your Social Standing Directly Affects your Health and Your Life Expectancy. London: Bloomsbury.

Marmot, M. ve Wilkinson, R.G (Ed). (1999). Social Determinants of Health. Oxford: Oxford University.

Marsh, L.C., Fleming, A.G. ve Blackler, C.F. (1938) Health And Unemployment. Some Studies of their Relationships. New York: Oxford University.

Mayhew, H. (1861). London Labour and the London Poor: Cyclopedia of the Condition and Earnings. London: Griffin, Bohnd and Company. https://archive. org/stream/londonlabourand01mayhgoog\#page/ n192/mode/2up (Erişim: 07.12.2014).

McCulloch, J. ve Tweedale, G. (2007). Science is not sufficient: Irving J. Selikoff and the asbestos tragedy. New Solutions, 17(4): 293-310.

McLoone, P. ve Boddy, F. (1994). Deprivation and mortality in Scotland, 1981 and 1991. British Medical Journal, 309(6967), 1465-70.

Meseri, R. (2008). Beslenme ve Genetiği Değiştirilmiş Organizmalar. TAF Preventive Medicine Bulletin, 7(5), 455-460. 
CDC (Centers for Disease Control and Prevention) Morbidityand Mortality Weekly Report. http://www. cdc.gov/mmwr/preview/mmwrhtml/00036609. htm (Erişim:11.01.2015).

Mooney, G. (2013). Ulusların Sağlığı: Yeni Bir Ekonomi Politiğe Doğru. (Çev.: Cem Terzi). İstanbul: Yordam.

Moyers, B. (2014). The Relentless Attack on Climate Scientist Ben Santer. http://billmoyers. com/2014/05/16/the-relentless-attack-of-climatescientist-ben-santer/ (Erişim: 12.01.2015).

Moynihan, R. ve Cassels, A. (2006). Satıllk Hastaliklar. (Çeviren: Gökçesu Tamer ve Evren Ylldırım). İstanbul: Hayy.

Navarro, V. (1998). Neoliberalism, "globalization," unemployment, inequalities, and the welfare state. International Journal of Health Services, 28(4), 607-82.

Navarro, V. (2002). A historical review (1965-1997) of studies on class, health, and quality of life: A personal account. V.Navarro (Ed.) The Political Economy of Social Inequalities: Consequences for Health and Quality of Life içinde (s.13-30). New York: Baywood.

Navarro, V. (2008). Neoliberalism and its consequences: The world health situation since Alma Ata. Global Social Policy, 8(2), 152-155.

Navarro, V. ve Mutaner, C. (2004). Political and Economic Determinants of Population Health and WellBeing: Controversies and Developments. New York: Baywood.

Oberoi, S., Barchowsky, A. ve Wu, F. (2014). The global burden of disease for skin, lung, and bladder cancer caused by arsenic in food. Cancer Epidemiology, Biomarkers \& Prevention, 23(7), 1187-94.

Ong, E. ve Glantz, S.A. (2000). Hirayama's work has stood the test of time. Bulletin of the World Health Organization, 78 (7), 938-9.

Prudham, S. (2004). Poisoning the well: neoliberalism and the contamination of municipal water in Walkerton, Ontario. Geoforum, 35(3), 275-283.
Prüss-Üstün, A. ve Corvalan, C. (2006). Preventing Disease Through Healthy Environments. Geneva: World Health Organization. http://www.who.int/ quantifying_ehimpacts/publications/preventingdisease.pdf, (Erişim: 11.01.2015).

Quinlan, M. ve Bohle, P. (2009). Overstretched and unreciprocated commitment: reviewing research on the occupational health and safety effects of downsizing and job insecurity. International Journal of Health Services, 39(1), 1-44.

Rantanen, J. (2010). Grand Challenges for Occupational Health from Globalization. Journal of Occupational Safety and Health, 18, 167-171.

Reichert, A. ve Tauchmann, H. (2011). The Causal Impact of Fear of Unemployment on Psychological Health. Ruhr-Universitat Bochum Department of Economics Working Paper No. 266. http://dx.doi. org/10.2139/ssrn.1880938 (Erişim: 09.12.2014).

Sanwald, A. ve Theurl, E. (2014). Atypical Employment and Health: A Meta-analysis. University of Innsbruck Working Papers in Economics and Statistics. http://eeecon.uibk.ac.at/wopec2/repec/inn/wpaper/2014-15.pdf

Scambler, G. ve Higgs, P. (1999). Stratification, Class and Health: Class Relations and Health Inequalities in High Modernity. Sociology, 33(2), 275-296.

Sen A. (2001). Economic progress and health. D.Leon ve G.Walt (Ed.) Poverty, Inequality and Health içinde (s.333-346). Oxford: Oxford University.

SGK (Sosyal Güvenlik Kurumu). (2012). SGK İstatistik Yillığı 2012.

Shanon, J. (2014). Food deserts: Governing obesity in the neoliberal city. Progress in Human Geography, 38(2) 248-266.

Spronk, S. (2010). Water and Sanitation Utilities in the Global South: Re-centering the Debate on "Efficiency". Review of Radical Political Economics, 42(2), 156-174. 
Stellman, S.D. ve Resnicow, K. (1997). Tobacco Smoking, Cancer and Social Class. M. Kogevinas, N. Pearce, M. Susser ve P. Boffetta (Ed.), Social Inequalities and Cancer içinde (s.229-50). Lyon: IARC Scientific.

Stuckler, D. ve Nestle, M. (2012.) Big Food, Food Systems, and Global Health. Plos Medicine, 9(6), http://www.alames.org/documentos/bigfood.pdf (Erişim: 18.12.2014).

Sullivan, D. ve von Wachter, T. (2009). Job displacement and mortality: an analysis using administrative data. Quarterly Journal of Economics, 124(3), 1265-1306.

Süyür, H. (2009). Polivinil klorür maruziyetinin pulmoner sisteme etkileri. Yayınlanmamış Tipta Uzmanlık Tezi. Gaziantep: Gaziantep Üniversitesi.

Tahaoğlu, K., Kongar, N., Elbek, O., Tümer, Ö. ve Kılıçaslan, Z. (2012). Türk Tabipleri Birliği Tüberküloz Raporu. Ankara: Türk Tabipleri Birliği.

Terzi, C. (2010). Hekimler Geçerli ve Güvenilir Bilgi için Tibbi Literaüre Güvenemezler. Toplum ve Hekim, 25(5), 346-379.

Terzi, C. (2013). Şarlatan. C. Terzi, E.Yuvayapan, E. Beşer (Ed.), Kapitalizmin Kıskacında Doğa, Toplum ve Bilim: Onur Hamzaoğlu Olayı içinde (s.33-41). İstanbul: Yordam.

The Wall Street Journal. (1996, 25 Haziran). Letters to the Editor: No Deception in Global Warming Report. http://stephenschneider.stanford.edu/Publications/PDF_Papers/WSJ_June25.pdf (Erişim: 20.12.2014).

Thomson, J., Lin, M., Halliday, L., Preston, G., McIntyre, P. ve Gidding, H. (1998). Australia’s Notifiable Disease Status 1998 - Annual report of the National Notifiable Diseases Surveillance System. Communicable Diseases Intelligence, 23, 277-305.

TMMOB (Türkiye Mühendis ve Mimar Odaları Birliği). (2008). Tuzla Tersaneler Bölgesindeki Çalışma Koşulları ve Önlenebilir Seri İş Kazaları Hakkında Rapor. İstanbul: TMMOB.
TTB (Türk Tabipleri Birliği). (2009). Hekimlerin Değerlendirmesi ile Performansa Dayalı Ödeme. Ankara: TTB. http://www.ttb.org.tr/kutuphane/performansadayaliodeme.pdf (Erişim: 12.04.2010)

U.S. Bureau of Labor Statisitics. (2013). A Profile of the Working Poor 2010, http://www.bls.gov/cps/ cpswp2010.pdf (Erişim: 12.12.2014).

UNDP (United Nations Development Programme). (2014). Press Releases. Launching of the Green Roof at the Central Bank main branch in Hamra. Press Releases. http://www.lb.undp.org/ content/lebanon/en/home/presscenter/pressreleases/2014/06/30/launching-of-the-green-roof-atthe-central-bank-main-branch-in-hamra/ (Erişim: 20.12.2014).

UNDP (United Nations Development Programme). (2014b). United Nations World Food Programme Hunger Statistics. http://www.wfp.org/hunger/ stats (Erişi̧im: 10.12.2014).

Üstündağ, N. ve Yoltar, Ç. (2007) Türkiyede Sağlık Sisteminin Dönüşümü: Bir Devlet Etnografisi. N. Üstündağ, T. Ağartan ve Ç. Yoltar (Ed.), Avrupa'da ve Türkiye'de Sağllk Politikaları içinde (s.55-94). İstanbul: İletişim.

WB (World Bank). (2004). Making Services Work For The Poor: World Development Report 2004. Washington: World Bank. https://openknowledge. worldbank.org/bitstream/handle/10986/5986/ WDR\%202004\%20-\%20English.pdf? sequence $=1$ (Erişim: 11.12.2014).

WHES (World Hunger Education Service). (2014). 2014 World Hunger and Poverty Facts and Statistics. http://www.worldhunger.org/articles/Learn/ world\%20hunger\%20facts\%202002.htm\#Does_ the_world_produce_enough_food_to_feed_everyone (Erişim: 19.12.2014).

WHF (World Heart Federation). (2012). Urbanization and Cardiovascular Disease. http://www.worldheart-federation.org/fileadmin/user_upload/ documents/Fact_sheets/2012/Urbanization_and_ CVD.pdf (Erişim: 21.12.2014). 
White, K. (2002). An Introduction to the Sociology of Health and Illness. London: Sage.

WHO (World Health Organization). (1978). Declaration of Alma-Ata. http://www.who.int/publications/ almaata_declaration_en.pdf (Erişim: 21.04.2014)

WHO (World Health Organization). (2009) Global Health Risks. Mortality and burden of disease attributable to selected major risks. http://www.who.int/ healthinfo/global_burden_disease/GlobalHealthRisks_report_full.pdf (Erişim: 12.12.2014).

WHO (World Health Organization). (2010a). WHO Bulletin 88(4). http://www.who.int/bulletin/volumes/88/4/10-010410/en/ (Erişim: 21.12.2014).

WHO (World Health Organization). (2010b). Urban Health. http://www.who.int/worldhealthday/2010/media/whd2010faq.pdf?ua=1 (Erişim: 22.12.2014).

WHO (World Health Organization). (2014a). Workrelated ill health and occupational disease. http:// www.hse.gov.uk/Statistics/causdis/index.htm (Erişim: 18.12.2014).

WHO (World Health Organization). (2014b) Clolera. Fact Sheet No.107. http://www.who.int/mediacentre/factsheets/fs107/en/ (Erişim: 16.12.2014).

WHO (World Health Organization). (2014c) Global Alert and Response (GAR): Cholera outbreak, South Sudan http://www.who.int/csr/don/2014_05_30/ en/ (Erişim: 16.12.2014).

WHO (World Health Organization). (2014d) 10 Facts On Cholera. http://www.who.int/features/factfiles/ cholera/en/ (Erişim: 16.12.2014).

WHO (World Health Organization). (2014e) Investing in Water And Sanitation: Increasing Access, Reducing Inequalities. GLAAS Report. http://apps.who.int/iris/bitstream/10665/139735/1/9789241508087_eng.pdf (Erişim: 18.12.2014).
WHO (World Health Organization). (2014f) Cancer. Fact Sheet No:297. http://www.who.int/mediacentre/factsheets/fs297/en/ (Erişim: 18.12.2014).

WHO (World Health Organization). (2014g). 7 million premature deaths annually linked to air pollution. News Releases. http://www.who.int/mediacentre/news/releases/2014/air-pollution/en/ (Erişim: 12.01.2015).

WHO (World Health Organization). (2014h). Preventing waterborne disease. WHO Preventing environmental health-related disease in health care and other settings. http://www.who.int/phe/ events/wha_66/flyer_wsh_water_borne_disease. pdf?ua $=1$ (Erişim: 16.12.2014).

WHO (World Health Organization). (2014i). Types of Healthy Settings: Healthy Cities. http://www. who.int/healthy_settings/types/cities/en/ (Erişim: 14.01.2015).

WHO (World Health Organization). (2014j). Obesity and overweight. Fact Sheet No:311. http://www. who.int/mediacentre/factsheets/fs311/en/ (Erişim: 12.01.2015).

Wilkinson, R.G. (1996). Unhealthy Societies: The Afflictions of Inequality. London: Routledge.

Wilkinson, R.G. (2000). Mind the Gap: Hierarchies, Health and Human Evolution. London: Weidenfeld and Nicolson.

Yavuz, M. (2010). Sağlıkta dönüşüm ve genel sağlık sigortası: Finansmanda yaşanan sorunlar. TES-İŞ Dergisi, Nisan, 94-101.

Yüksel, İ. (2003). İşsizliğin psiko-sosyal sonuçlarının incelenmesi:Ankara örneği. Cumhuriyet Üniversitesi İktisadi ve İdari Bilimler Dergisi, 4(2), 21-38.

Zwi, A.B., Forjuoh, S., Murugusampillay, S. Odero, W. ve Watts, C. (1996). Injuries in developing countries: policy response needed now. Transactions of the Royal Society of Tropical Medicine and Hygiene, 90(6), 593-95. 